\title{
A Review of the Progress of COVID-19 Vaccine Development
}

\author{
COVID-19 Aşısı Geliştirme Süreci Üzerine Bir Değerlendirme
}

\section{Sami ULLAH}

(i) 0000-0002-9669-5737

Abdullah Ghodran AL-SEHEMI ${ }^{1}$

(D) 0000-0002-6793-3038

Jiř́i Jaromír KLEMEŠ 2

(D) 0000-0002-7450-7029

Sanam SAQIB ${ }^{3}$

(D) 0000-0002-4026-660X

Sahibzada Muhammad Azib GONDAL

(D) 0000-0002-4065-5066

Sidra SAQIB ${ }^{5}$

(i) 0000-0003-2325-2393

Akasha ARSHAD 6

(D) 0000-0001-9864-6034

Hira SAQIB ${ }^{7}$

(D) 0000-0002-7938-3555

Ahmad MUKHTAR ${ }^{8}$

(D) 0000-0003-3367-5963

Muhammad IBRAHIM 9

(D) 0000-0003-4624-1849

Saira ASIF 2,10 $^{2}$

(D) 0000-0001-8185-0653

Awais BOKHARI ${ }^{2,5}$

(1) 0000-0002-0748-6336

\begin{abstract}
A coronavirus disease pandemic (COVID-19) is still a global problem with not sufficient evidence of a declining pattern caused by severe acute respiratory syndrome coronavirus 2 (SARS-CoV-2). It is generally accepted that normal life is impeded by securing a reliable vaccine strategy. Many countries have accelerated the process of clinical trials to create effective treatment with COVID-19. More than 200 candidate vaccines have been started for SARS-CoV-2 testing. This review attempts to provide an overview of the currently emerging COVID-19 vaccine types, address the theoretical and practical challenges of vaccines for COVID-19 and discuss possible strategies to help vaccine design succeed. The first move was to take out papers using the initial keyword "pandemics, vaccines and vaccine types". A total of 63,538 results (including 1,200 journals; 16,875 books; and 12,871 web pages), with the initial keyword, searched for in the Scopus database. Further improvements were searched on keywords such as "pandemic and vaccine types" (711 newspapers and 5,053 webpages). This review attempts to overview the historical and important basic information about the pandemics viz. history, virological characteristics, structure, origin and physio-chemical properties. The second phase includes the vaccination types and strategies in depth. It includes the diagnosis, virology and pathogenesis of SARS-CoV-2 and SARS-COV-2/COVID-19 vaccines. The development, planning strategies, types, cost and current scenarios of COVID19 vaccines are depicted in detail. The pandemic COVID-19 as it continues, is a global problem. Vaccination seems to be an efficient and economical way to mitigate and control the epidemic. This requires a mass production of successful COVID-19 vaccines.

Keywords: SARS-CoV; COVID-19; vaccines; vaccine types; assessments and implications.
\end{abstract}

\section{ÖZ}

Affiliations of the authors are given on Koronavirüs hastalığı (coronavirus disease 2019, COVID-19) pandemisi, şiddetli akut the following page.

\section{Corresponding Author Sorumlu Yazar \\ Jiří Jaromír KLEMEŠ \\ jiri.klemes@vutbr.cz}

Received / Geliş Tarihi : 15.01 .2021 Accepted / Kabul Tarihi : 14.02.2021 Available Online /

Çevrimiçi Yayın Tarihi : 02.03.2021 solunum yolu sendromu koronavirüsü 2 (severe acute respiratory syndrome coronavirus 2 , SARS-CoV-2)'nin neden olduğu ve henüz hastalığın olumsuz etkilerinin azalmasına yönelik yeterli kanıtın bulunmadığı küresel bir sorundur. Güvenilir bir aşı stratejisinin geliştirilmesiyle normal yaşama dönüleceğine dair genel bir fikir birliği oluşmuştur. Birçok ülke, COVID-19'a karşı etkin tedavi geliştirmek için klinik araştırma sürecini hızlandırmıştır. SARS-CoV-2 için 200 'den fazla aday aşı test edilmeye başlanmıştır. Bu çalışmada, güncel COVID-19 aşı türleri genel olarak gözden geçirilecek, COVID-19 aşılarının teorik ve pratik zorlukları incelenecek ve aşı tasarımının başarılı olmasına yardımcı olacak olası stratejiler tartışılacaktır. Çalışmanın ilk bölümünde, anahtar kelimeler olarak "pandemiler, aşılar ve aşı türleri" kullanılarak literatürde yer alan makaleler incelenmiştir. Scopus veritabanında başlangıç anahtar kelimeleri ile toplam 63.538 sonuç (1.200 dergi, 16.875 kitap ve 12.871 web sayfası) incelenmiştir. Daha sonra "pandemi ve aşı türleri" gibi anahtar kelimeler ile daha ayrıntılı arama yapılmıştır (711 gazete ve 5.053 web sayfası). Bu çalışmada ayrıca, pandemilerle ilgili tarihsel arka plan, virolojik özellikleri, yapısı, kökeni ve fizyo-kimyasal özellikleri de incelenmiștir. İkinci bölümde, aşılama türleri ve stratejileri derinlemesine araştırılmıştır. Bu bölümde, SARS-CoV2 ve SARS-COV-2/COVID-19 aşılarının teşhisi, virolojisi ve patogenezi üzerinde durulmuştur. COVID-19 aşılarının geliştirilmesi, planlama stratejileri, türleri, maliyeti ve güncel senaryoları ayrıntılı olarak açıklanmıştır. COVID-19 pandemisi var olduğu sürece küresel bir sorun olmaya devam edecektir. Aşılama, bu salgını hafifletmek ve kontrol altına almak için etkili ve ekonomik bir yol olarak görünmektedir. Bu hedefe ulaşmak için, etkin COVID-19 aşılarının seri üretimi en başarılı yol olacaktır.

Anahtar kelimeler: SARS-CoV; COVID-19; aşılar; aşı tipleri; değerlendirme ve çıkarımlar. 
${ }^{1}$ King Khalid University College of Science Department of Chemistry, Abha, Saudi Arabia

${ }^{2}$ Brno University of Technology Faculty of Mechanical Engineering Sustainable Process Integration Laboratory, Brno, Czech Republic

${ }^{3}$ Rawalpindi Medical University, Rawalpindi, Punjab, Pakistan

${ }^{4}$ Fauji Foundation Hospital, Rawalpindi, Punjab, Pakistan

${ }^{5}$ COMSATS University Islamabad Department of Chemical Engineering, Punjab, Pakistan

${ }^{6}$ Red Crescent Medical and Dental College, Lahore, Pakistan

${ }^{7}$ University of Education, Punjab, Pakistan

${ }^{8}$ NFC Institute of Engineering and Fertilizer Research Department of Chemical Engineering, Faisalabad, Pakistan

${ }^{9}$ Government College University Faisalabad Department of Environmental Sciences and Engineering, Punjab, Pakistan

${ }^{10}$ PMAS Arid Agriculture University Faculty of Sciences Department of Botany, Rawalpindi, Punjab, Pakistan

\section{INTRODUCTION}

The severe acute respiratory syndrome coronavirus 2 (SARS-CoV-2) has a place in a family of coronaviruses, which is a family known as zoonotic infections, and which sorts betacoronavir and is closely associated with two other infections, including severe acute respiratory syndrome coronavirus (SARS-CoV) and the Middle East respiratory syndrome coronavirus (MERS-CoV). It should be cover in an icosahedral shell of protein. The surface has different club-shaped spikes; the electron microscopy (EM) reveals a sun-faced crown. The surrounding virus contains a lipid bilayer in which auxiliary proteins are protected for layer (M), envelope (E) and spike (S). Both coronaviruses are used as receptors of cellular passage by angiotensinconverting protein. In any event, the propensity of SARSCoV-2 to join these receptors is far higher, and it has strong infectivity (1). The various variants of the coronavirus disease 2019 (COVID-19) virus circulate around the world: the United Kingdom (UK) has reported the B.1.1.7 strain with a large number of mutations in the fall of 2020. This version is simpler and quicker to spread than other variants. Experts in the UK stated in January 2021 that the risk of this variant was higher than the other variant viruses, but more studies are needed to confirm it. In several countries around the world, it has since been identified. This version was first observed in the United States in late December 2020. Another edition named B.1.351 appeared in South Africa separately from B.1.1.7. B.1.351 shares certain mutations with B.1.1.7 originally detected in early October 2020 (2). At the end of January 2021, cases arising from this variant were registered in the USA. A P.1 variant, first observed in Brazilian travelers who had routine check-ups checked on an airport in Japan in early January, was established in Brazil. This modification includes a variety of other mutations, which can impact the ability of antibodies to be recognised. In the USA, at the end of January 2021, this variant was first observed (3).

\section{NEED FOR CORONAVIRUS VACCINE}

The active sedation against infection or the subsequent infection was severely examined and no operators were moved further. There have been several medications, primarily hydro-xychloroquine and resuscitation advocated as frenetic steps to tackle COVID-19 on the basis of a vast number of preparatory, contradictory and ambiguous studies. These and other medicines can save lives but do not shut their doors to regularity in the expressed turmoil of the pandemic. It brings us, as it was, to a particular option of a successful and stable antibody, which must be rendered as long as all nations and communities influenced by the widespread at fair prices may conceive and accessible (1).
Vaccination may build an insensitivity of the crowd inside a society that can decrease the disease incidence, minimise square transmission and reduce the social and financial impact of the disease. Except for a widespread vaccine scope, an auxiliary contamination wave can be prevented, and frequent endemic disease revolutions can be regulated. Finally, the disease could be murdered, as it was in many other illnesses with a higher potential to cause pandemics such as smallpox, poliomyelitis, etc. than COVID-19 (2).

HISTORY OF VACCINES FOR CORONAVIRUSES A single-stranded positively receptive RNA genome is encircled by coronaviruses, which have an expansive $(30+\mathrm{kb})$, helical nucleocapsid $(\mathrm{N})$ and an exterior surface consisting of a protein grid $\mathrm{M}$, a protein $\mathrm{E}$ or S proteins (3). The $S$ protein, usually trimeric, includes the space for the receptor retention (RBD) that can officially be converted into the angiotensin over the protein 2 (ACE2) and into the cell (Figure 1). S protein has been shown to elicit a neutralising counteracting agent in SARS-CoV, all of the essential proteins, and maybe a main vaccine antigen target (4). The progression of coronavirus immunisations has been verified with issues. In the animal models that mimic human disease, coronavirus antibodies were immunogenic and it mostly ineffective in preventing infection securing. There is fear; however, that inoculation might not be practicable for long-lived insusceptibility, as with a typical coronaviral illness, and reinfection may be conceivable. Improvement of illness linked to immunisation in several cases. Former usage of certain animal models of coronaviral antibodies (SARS-CoV and MERS-CoV) posed protection issues with Th2, and immunopathology interfered. Two days after the SARS-CoV challenge was not found in the lungs of threatened non-vaccinated mice, mice vaccinated with two inactivated whole infection antibodies, recombinant DNA spicy protéine immunisations or viral molecule vaccines produced a lung pathology counting eosinophilic penetration (5).

In a few other ponders, comparison with younger muses who have been challenged in the process of taking postimmunisation, comparable lung immunopathology is found. The SARS-CoV N protein immunisation inocular mouse induces extreme pneumonia or pulmonary eosinophilic occurrence in viral disease, whereas the $\mathrm{N}$ protein antigen may not be an antigen linked with the viral copy of particles communicating glycoprotein, which is recommended by the mouse immune system. In mice with inactive MERS-CoV vaccination when threatened by live infections, comparable enhanced immunopathology was observed (6). 
Upgrading contagious antibody linked may be more nervous for certain kinds of antibody. Improved viral disease infection took a major position after the inactivation of measles and RSV vaccinations. The possible components are the Th2 warped reaction arising from formalin inactivation and the need for liquid antibody development (7).

\section{VIROLOGICAL CHARACTERISTICS OF SARS-COV-2} The causative pathogen of COVID-19 is SARS-CoV-2, with the coronaviridae family as its place. Near after other $\beta-\mathrm{CoVs}$, the $\sim 3-\mathrm{kb}$ genome-estimated SARS-CoV-2 virion comprises a nucleocapsid of genomic RNA and the nucleocapsid phosphorylated (N) protein (8). Nucleocapsids are inserted in bilayers of phospholipids and enclosed in the two separate kinds of spiking proteins: spiken glycoprotein-trimmers demonstrate in both CoVs. The S protein plays an important function in receptor authority and its the gateway to the determination of tropism and transmitting capability (Figure 2). On the side of the viral envelope, the lattice protein $(\mathrm{M})$ is located within the viral envelope. Genome analysis showed that SARS-CoV-2 comprises 5 and 3 terminal groupings with a quality structure 5 -free screen perusing (ORF).

Particles of the infection are 60-100 nm long and spherical or oval (9). It may be inactivated or warmed at $56{ }^{\circ} \mathrm{C}$ for 30 minutes by light and touches much of the disinfectants (i.e. ether, $75 \%$ ethanol, per acetic, chlorine and chloroform) (10). Collection of evidence indicates that SARS-CoV-2 is comparable to the human cell receptor SARS-CoV-2 (ACE2), whereas the pivotal dipeptidyl peptidase-4 pivotal MERS-CoV is similar to the cell-section. Collection of the data ACE2 can be a kind of film I protein, mostly linked to cardiovascular infections, communicated within lungs, hearts, kidneys and digestion tracts. Later analysis of the cryogenic electron microscope structure of the SARS-CoV-2 S protein showed that ACE2 is approximately 10 to 20 times more official than SARS-CoV.

As for the phylogenetic analysis of the genomes SARS-CoV-2, after a review of the test globally, analysts found three key differences, A, B and C. A as the genealogical genus in line with the bat outgroup CoV. Interestingly, East Asia and the European States are greatly external to kinds of A and C. By contrast, B is the most predominant species in East Asia, and its ancestors do not tend to disperse beyond East Asia without being presumed category B. SARS-CoV-2 genomes have been detected as strongly interrelated, and human evolution has been taken on a variety of instances in parallel, where the same viral transition takes place in two separate human beings (11).

Due to its whimsical aspect and its strong contagiosity, it is of exceptional importance to track SARS-CoV-2 continuously from humans or creature organisms.

\section{STRUCTURE AND ORIGIN OF CORONAVIRUS}

Coronavirus is a packaged infection, and RNA belongs to the Coronaviridae family, the Coronavirinae family, and organise Nidovirales, with one stranded, non-segmented and positive sensory infections. The coronavirus genome estimate is approximately $26-32 \mathrm{~kb}$ and is the major recognised RNA infection genome. Its dimensions vary from a gap of $60 \mathrm{~nm}$ to $140 \mathrm{~nm}$ through club estimates of the spike (Figure 1). Beneath the lens, the spike appears like a coronavirus (12). Helically symmetrically, coronavirus has nucleocapsides, which is unusual in positive sensory RNA infections. The subfamily, which is phylogic, comprises of four genera: alpha-CoV, betacoronavirus $(\beta-\mathrm{CoV}), \quad$ gamma-CoV and deltacoronavirus $(\mu-\mathrm{CoV})$. This is a genetic part of the Coronavirin. $\alpha-\mathrm{CoV}$ and $\beta-\mathrm{CoV}$ normally causes human air problems, whereas $\mu-\mathrm{CoV}$ and $\mu-\mathrm{CoV}$ deflect mammals.

Extreme respiratory disease induced by four human coronavirals, HCoV-NL63, HCoV-OC43, HCoV-229E and HKU1, was a deeply pathogenic human virus, which caused extreme respiratory syndromes in humans. HKU1 began in rat, and HCoV-NL63, HCoV-229E, SARS-CoV, and MERS-CoV were started from bats in conjunction with the latest sequence database HCoV-OC43 (13). Sequencing reveals that $\beta$-coronavirus is present in $\mathrm{nCoV}$ 2019. In 2003, beta-gener coronavirus with bat-root in the Guangdong region of China transmitted to humans through civet cat. This infection triggers extreme respiratory syndrome, and in China and Hong Kong, around 8,422 people were infected. Another epidemic occurred in Saudi Arabia in 2012 with 2494 individuals influenced, and $34 \%$ of casualties (CE) recorded in the MERS-CoV.

\section{TRANSMISSION}

In December 2019 in Wuhan, Hubei Province, China, a novel $\beta$-coronavirus was to start. The third plague of the twenty-first century, now exceeding SARS and MERS, in China. Right now, an immense amount of pneumonia patients who were subjected to fish ads were detailed, which may be a centre for many live creature organisms. The entire COVID-19 genome groups were dumped into an open database in 10 January 2020 and noticed that there is a certain similarity to SARS. The International Scientific Categorisation Committee for Infections 2019-nCoV was renamed as SARS-CoV-2. The inherited COVID-19 arrangement reveals about $80 \%$ similarity to the SARS$\mathrm{CoV}$ and $50 \%$ proximity to the MERS-CoV (14). A detailed analysis of phylogenetics has shown that the COVID-19 belongs to the family of beta-coronavirus. The receptor authorship is the key stage in viral disease after cell fusion.

It is known that the interactions between COVID-19 and angiotensin-transforming chemical 2 (ACE2) have been contrasted with the SARS-CoV in the classification of coronavirus spike official space receptors. On 17 November 2019 , the number of coronavirus cases in Wuhan, China increased exponentially. The coronavirus easily spreads from China to other countries including Thailand, Nepal, Malaysia, Sri Lanka, Singapore and, jointly, the Philippines, India, Australia, Finland, Germany, Cambodia, Vietnam, Taiwan, Canada, Japan, France (Figure 2). WHO has declared the novel Coronavirus episode generally recognised and illustrated the call for urgent action from all countries in detecting, managing, and reducing dissemination to save lives. The WHO detailed $8.9 \mathrm{M}$ cases of coronavirus at the time of the planning composition and approximately $0.4-0.5 \mathrm{M}$ cases of. Some sources suggest 
personal-to-person correspondence through teamwork contacts; the courses for the transmitting of COVID-19 are through efficiency hacking or sneesing of a tainty individual and roundabout touching, for instance, surface defilement. Other experts were researched on pregnant ladies who were affirmed for COVID-19 disease in the third trimester of pregnancy, but mother-to-child transmission did not reinforce this. Pregnant people are more susceptible to respiratory pathogens infection (15).

\section{SYMPTOMS AND DIAGNOSIS}

Fever, hacking and exhaustion are typical side effects of this infection. A few patients may have defining signs such as throbbing, nasal blockage, sputum generation, hemoptysis, nose running, a sore jaw, loose bowels, lymphopenia and dyspnoea. Following hatching, the signs turn up for around 5.2 days (16). The duration from coronavirus disease starting to death differs between 6 and 41 days, with an intermediate of 14 days. Patient vulnerability and age depend on the time of infection. In patients $>70$ years of age, the duration of diseases is shorter than those below 70 years of age. Chest CT philtres shown as pneumonia, intensive reflex sympathetic dystrophy (RSD), extreme renal injury, heart hurt and, indeed, passing can occur in serious cases clinical characteristics shown as Chest CT philtres. Numerous ground glass turbulence observed in a few patients in the subpleural location of the lungs, which triggered both localised and healthy reactions leading to inflammation (17).

The upper lungs flap, connected to dyspnea and hypoxemia, is defined by chest radiology of certain patients. The faecal and pee tests are also necessary to include an elective coronavirus transmitting course, as patients that have been infected with COVID-19 also create side effects such as looser bowels. The amounts of the pro-inflammatory cytokine, large numbers of leukocytes, and exceptional respiratory work tend to be rising in coronavirus infected patients. Severe pneumonia, soil opacities RNAaemia and acute hearts injury are the most pathogenesis of COVID-19 infection. Top of cytokine and chimiocine amounts, such as the TNF- $\alpha$, IL7, IL8, IL9, IL10, VEGFA, GCSF, GMCSF, PGF2, etc. occur in blood in patients with COVID-19 (18). Air studies are carried out from a spotty person both symptomatic and asymptomatic and are forwarded to a testing centre for inference: the nasopharyngeal swab, swab, sputum, throat swab, bronchaeolar lavage. The example was evaluated using the convention distributed by WHO with a reverse transcription chain response (RT-PCR). If the number of patients grew on a regular basis, this contributes to a shortage of atomic test capability and reagents dependent on the laboratory. Quick and easy to use gadgets were produced for the external test of the testing setup in a few minutes. It is much tougher to seek rectifications in the antibody-based monitoring device since a counteracting agent will identify infection antigens other than COVID-19 that induce common cold inside the strip. In order to solve this issue, a simple determination test for patient treatment was developed for the counteracting agent. This fast kit established the counteracting agent in the blood following infection by COVID-19. The intensity of the response of counteracting agents depends on the severity of the illness, the age of the patient, the medical state, the patient's medications etc. (19). Table 1 contained the most commonly distributed demonstrative kits.

Table 1. Some of the diagnostic test kits used for the diagnosis of COVID-19 (20)

\begin{tabular}{ll}
\multicolumn{1}{c}{ Product Name } & \multicolumn{1}{c}{ Manufacturer } \\
\hline cobas SARS-CoV-2 Qualitative assay for use on the cobas 6800/8800 Systems & Roche Molecular Systems, Inc. \\
Primerdesign Ltd COVID-19 genesig Real-Time PCR assay & Primerdesign Ltd \\
Abbott Realtime SARS-CoV-2 & Abbott Molecular Inc. \\
PerkinElmer $®$ SARS-CoV-2 Real-time RT-PCR Assay & PerkinElmer Inc. \\
Real-time fluorescent RT-PCR kit for detecting 2019-nCoV & BGI Europe A/S \\
Detection Kit for 2019 Novel Coronavirus (2019-nCoV) RNA(PCR-Fluorescence Probing) & Da An Gene Co., Ltd. Of Sun Yat-sen University \\
RealStar SARS-CoV-2 RT-PCR kit 1.0 & Altona Diagnostics \\
Patho Detect & MY LAB \\
Allplex 2019-nCoV assay & Seegene \\
nCoV Real-Time Detection kit & SD Biosensor \\
TRUPCR SARS-CoV-2RT-qPCR kit version 2 & KILPEST (BLACKBIO) \\
Quantiplus CoV detection KIT Ver 2.0 & Huwel Lifesciences Pvt. Ltd. \\
TaqMan 2019-nCoV Control Kit v1 & ABI (Applied biosystems) \\
BIO COVID ID/ COVID-19 qualitative PCR detection Kit version 2 & Biogenomics (India) \\
qSARS-CoV-2 IgG/IgM Rapid Test & Cellex, Inc. \\
Quest SARS-CoV-2 rRT-PCR & Quest Diagnostics Infectious Disease, Inc. \\
EverlyWell COVID-19 Test Home Collection Kit & Everlywell, Inc. \\
COVID-19 RT-PCR Test & Laboratory Corporation of America (LabCorp) \\
Panther Fusion SARS-CoV-2 Assay & Hologic, Inc. \\
TaqPath COVID-19 Combo Kit & Thermo Fisher Scientific, Inc. \\
Xpert Xpress SARS-CoV-2 test & Cepheid \\
\hline
\end{tabular}




\section{CLINICAL FEATURES AND SUSCEPTIBILITY}

Persons of any age level would not be allowed to utilise COVID-19. Indications during the normal flu (Flu), include fever, hack, an ailment of the mouth, migraine, tiredness, myalgia, smell and taste misfortune and dyspnea. In asymptomatic or mellow infections up to $80 \%$ of the cases have (21). Simple co-morbidities in a few patients may help to exacerbate the illness, influenza, intensive respiratory diseases (ARDS) and multiorgan fractures, and in a long-term, fatal at the end of the primary week.

\section{PHYSICOCHEMICAL PROPERTIES}

SARS-CoV-2 can be practical on surfaces like the sodium hypochlorite, hydrogen peroxide, diatyle ether, $75 \%$ ethanol, chlorine etc. on surfaces of plastic and stainless steel up to $72 \mathrm{~h}$ under positive environment conditions but is prone to the most typical disinfectant compounds. The cleanser has also been seen to work as the lipid bilayer of the bacteria breaks down promptly. Moreover, UV inactivating or warming at $60{ }^{\circ} \mathrm{C}$ for $30 \mathrm{~min}$ can be achieved for SARS-CoV-2 (22).

DIAGNOSIS AND PATHOGENESIS OF SARS-CoV-2 The quick and accurate conclusion of COVID-19 is critical for managing the outbreaks in populations and centres of healing (23). The ideal demonstration research for CoVs was carried out with developments such as polymerase chain response (PCR), reverse-transcription polymerose chains (RT-PCR), Real-Time RT-PCR (rRT-PCR), invert translation isothermal loop controlled change (RT-Light). PCR testing has been performed to date on the leading edge of SARS-CoV-2. As the gold standard used to identify the disease source, PCR prevails that the requisite preliminary steps will normally be generated easily until the virus system is established (Figure 4). Prior to the identification of the virus long time earlier, WHO initiated and disseminated in January 2020, the key quantitative RT-PCR steps to classify SARS-CoV-2. This evaluation convention was complex, costly and is basically ideal for broad centralised demonstrative testing facilities. All of this is taken into consideration. With regard to the demonstrative standards currently identified by the China National Wellness Board, the standardised COVID-19 evaluation has matured nasopharyngeal and oropharyngeal swab studies. Three new RT-PCR experiments were added, with slightly fewer in vitro discovery maximum, based on the polymerase of RNA (Rdrp)/helicase (Hel), nucleocapside and SARS-CoV-2 spike qualities (RdR). In conjunction with the one-step RT-PCR framework, the SARS-CoV E consistency discovery is popular. The PCR E-Quality was fine for SARS-CoV-2 disease diagnosis, while the RdRp Convention was accepted as positive proof.

\section{Diagnostic Testing for COVID-19}

Strictly speaking, a new FDA-licensed COVID-19 procedure has already been developed using Abbott ID. Presently, this diagnostic process will be delivered, all in order to try to draw a verdict in reasonably five minutes. As SARS-CoV-2 efficiency results can result in untrue negative effects, counteracting agent discovery may be accompanied in particular by enhancing the screening of asymptomatic individuals. Clinically, in any event with unfavourable RT-PCR findings, the assessment of the disorder COVID-19 should be carried out with ordinary chest computerised Tomography (CT) properties for those who are late suffering from headache, weariness, sore throat, hacking, or dyspnea due to introduction. Most instances showing the two-sided transmitting of sketchy shadows and dark glass, often with a ring shape, and a lungen conveyance, reveal comparable characteristics on the CT images (24).

In the 21 primary chest CT inspections, some of the knowledge transmitted from China revealed that widening patients $(86 \%)$ triggered iced glass nebula affecting more than one lung flap (71 \%). Moreover, lung cavitation, pleural emanation, covert aspirational knobs and lymphadenopathy were also significant. It should be found out that Expanding imaging creativity, and a later reflection shows the probability of saddling the Cas 13 SHERLOCK stage for the determination of SARS-CoV-2 (25). The Cas 13 protein is sent to classify those hereditary goals within this system. The Cas13 is allowed to cleave neighbouring RNAs, which are a 'collateral' function useful for amplification of a columnist flag. Whatever it is, a verified structure for clinical testing should be sponsored. Several of the knowledge transmitted from China revealed an expansive selection of patients $(86 \%)$ to develop iced glass nebulae with influences of more than one flap in the lung (71\%) (two-sided inclusion). Furthermore, lung cavitation, pleural emanations, distinct aspsic knobs, and lymphadenopathy were important. It should be noted that when extending to picture creativity, a later study reveals that SHERLOCK, based on Cas13, is saddled for the determination of SARSCoV-2 (25). For example, the Cas13-based step will saddle. In this sense, Cas13 protein is sent for RNAtargeting to identify unique genetic goals. Cas 13 will separate neighbouring RNAs, the 'collateral' highlight of which is useful to intensify the symptomised columnist flag. Whatever it is, a verified structure for clinical testing should be sponsored.

\section{Pathogenesis of SARS-CoV-2}

For SARS-CoV-2 transmissions, an effective viral Replication in the mucosal epithel of the upper respiratory tract is required to occur and promotes proliferation of the lower respiratory tube and gastrointestinal mucocious membranes, triggering mother viremia. Exceptionally, few pathogens are under surveillance at this stage and remain asymptomatic. Moreover, a variety of patients may be impacted by non-respiratory side effects (i.e. extreme cardiac and liver injury, deception of the kidney, runs). Since ACE2 is extensively distributed through the nasal mucosa, bronchus, lungen, cardiovascular and kidney, and so on, SARS-CoV-2 is defenceless in various human organs. In particular, $S$ protein plays a key role in evaluating the cell tropism and consequently, the transmission of SARS-CoV-2 interspecies as it has the effect of infection in a cellular receptor.

The spike protein would catalyse the viral combination handle, enabling the viral genome to reach the cytoplasm, after the receptor's official location. The division of $S$ into subunits, regarded as planning, is a prerequisite for this technique (Figure 3). Hoffmann et al.'s study has unmasked the usage of the ACE2 receptor for transient and the TMPRSS2 serine protease for $\mathrm{S}$ protein preparation by 
SarS-CoV-2. TMPRSS2 supported inhibitors for therapeutic usage will then position the entrance to offer an alternative to simple therapy. The fact that $\mathrm{S}$ will easily be able to get unused protease cleavage premises, as well as the fact that multiple proteases can conduct the same role, indicates that this disorder will effectively be modified to replicate in a few cell species (26).

The SARS-CoV-2 and SARS-CoV-CoV CoV (RBD), which had been detailed beforehand as incapable of transacting with $S$ protein, includes apparent antigene errors between SARS-CoV-2 and SARS-CoV, were all murine monoclonal anticuerpos (mAbs) and polyclonal antibodies (pAbs). The main neurotic study of severe COVID-19, based on neurotic analysis discoveries, indicates that cellular fibromyxoid exudates induced diffuse alveolar harm on both sides of the lung (27). The right lung revealed a fascinating arrangement of the hyaline and lung shedding and ARDS recommendation. In comparison, pneumonic edoema and the hyalin layer arrangement tended to clean away lung tissue, which indicates early ARDS. Lymphocytes have overwhelmed, in both lungs, interstitial Mononuclear Explosive Infiltrate. Another thought about how the passage of COVID-19 disease may often contribute to severe kidney damage and proteinuria.

In patients with COVID-19 ACE2 had been found to be upregulated, and the immunostaining agent of nuclear SARS-CoV counteracting protein in tubules had been positive. It was observed in many interstitial mononuclear fiery invasions, the cardiac tissue did not easily impact this infection (27). Apart from the severe respiratory disruption, overflowing provocative responses in the preparation of the disease were often found in clinical situations, contributing to aspiratory aggravation. It is important to remember that downregulation of ACE2 by viruses, rapid infection replication and cell damage and improvement depending on the antibody will lead to a strong deterioration caused by SARS-CoV-2. A large amount of epithelial and endothelial cells would be triggered by the beginning scheme of fast viral replication, and the seething of pro-inflammatory cytokines and chemokines (Figure. 5) will be encouraged subsequently. Intriguingly, the later study contrasted SARS-CoV-2's transcriptional reactions with other respiratory infections to discern between transcriptional highlights which could frame COVID-19's organic premise. The analysis reveals that SARS-CoV-2 is rare and commonly transcripted. Despite viral replication, the host responded to SARSCoV-2 and at the same times initiated high chemokine levels sufficient to pick the effector cells, resulting in productive reactions of Sorte I and II I interferon (IFN-I and -III). In other words, the moo amounts of IFN-I and III were typical of this kind of arson reaction in contrast to elevated chemokines and high IL-6 expression. The reduced intrinsic antiviral tolerance and plentiful fires of cytokine may be the main features of COVID-19.

As the weakened resistant reaction facilitates motivated viral reproduction, this fundamental observation may also justify why severe COVID 19 events are more commonly found in comorbidity patients. In expansion to a cytokine storm, some studies have shown that the typical function of COVID-19 can be lymphopenia, which can be too severe and trigger death (28).

\section{CRUCIAL SARS-CoV-2 TARGETS FOR NOVEL DRUG DEVELOPMENT}

The schematic of SARS-CoV-2's virology as well as the broad-reaching possible danger tools provide the foundation for care and expectation in particular. In the statistic, there is a general interpretation of immediate deadlines for sedate revelation. 6.-6. Inside the virus-cell receptor transaction, the part of the surface auxiliary $S$ is of particular intrigue for antiviral development. S1 subunit $\mathrm{mAbs}$ and $\mathrm{S} 2$-focused inhibitors are likely to have in vitro or in vivo capacities for anti-SARS-CoV-2. As ACE2 is essential to use for SARS-CoV-2 receptors, mAbs or atoms that depend on their receptors are viable in deciding pathogenesis against SARS-CoV-2 medicines, as long as they do not provide inspiration to immunologic effects on the animal models (29). The test was subsequently performed at a protein binding site COVID-19 $\mathrm{S}$ to the cell-surface receptor.

The effects of their observations showed a more desirable position between the official S-protein districts III and IV and GRP78. The most tractive drive for the official GRP78 is locale IV, which can be used to schedule preventive action against this infection (30). It was noticed that, notwithstanding the fact that protease inhibitors which have a combined Prime $\mathrm{S}$ antiviral activity, several inhibitors are important because $\mathrm{S}$ may use a variety of proteases in the preparation of this product. If they develop, prospective care applicants will be operators focused primarily on the well-preserved S2 subunit. The expansive polyproteins 1a (ppla) and pplab encoded by the ORF1a / $\mathrm{b}$ are subjected to two viral proteases, papainlike protease (PL professional) and cleavage 3C protease ( $\mathrm{M}$ master), for a non-substantive protein produced by viral translation and replication (Figure. 3) (31). (SARSCoV-2)

Then chemicals that concentrate on these proteins will display aggressive SARS-CoV-2 in vitro movement. Later thinking has revealed that the master M of SARS-CoV-2 is a cornerstone protein which intervenes in viral replication or translation (32) as interpreted polyproteins of ORF 1a / b. In fact, a Gln-residue needs an amino corrosive substrate at P1 almost continuously. There is now no $\mathrm{M}$ competent person like-minded, rendering it an antiviral goal that is promising (Figure. 6) (33). The antiviral staff 'systemic strategy for this protease by analysing the substrate-binding $\mathrm{M}$ master take had been performed by Dai and colleagues (32). In this regard, an emphasis on such a protease can lead to certain antiviral sedate candidates.

However, the chemicals that interface the acyl chain with $\mathrm{S}$ have not been detected, but the cellular proteins are, as part of the substratum specificities, acetylated by the ZDHHC family. In the absence of acetylation in aviation cells inside the lung's route, a variety of them will stifle viral reproduction, and cellular protein acylation can become dangerous once in a while. The emphasis on acyl transferases can, in this sense be promising as the set of cysteine occurs in all $\mathrm{CoV}$ form $\mathrm{S}$, indicating contempt for its source (34). In any case, if the proteins of intrinsic protection reaction are altered by the same proteins as the viral proteins in the light of the palmitoylation of pivotal proteins inside the natural resistance, the inhibitor of acylation may be decreased. As Bojkova et al. expanded, 
the cell paths balanced by SARS-CoV-2 disease were late differentiated, and it was discovered that concealment would prevent viral replication in human cells.

Notes the SARS-CoV-2 infection profile was decided at different times following contamination by translatom 3 and proteome proteomics, recommending that this contaminated disease could re-shape central cell tracts. Similarly, spliceos can also be the future aims for some antagonists and glycolysis inhibitors. The last argument is the usage of tiny RNAs (siRNAs) interferometers. SARSCoV-2 will collapse into cells and release the nucleocapsid and viral RNA to the cytoplasm and then, for genomic RNA replication, interpreted the ppla and pp1ab ORF1a / b. SARS-CoV-2 diseases may then play a role in siRNAs with an emphasis on basic genes and can render them clinically relevant via the enhancement of SiRNAs transport in vivo.

\section{SARS-CoV-2/COVID-19 VACCINES}

Creating and scaling up mass immunisation production in a global context rapidly and broadly is difficult because, in comparison to a typical decade of successive planning in the process of preclinical trials, phases of clinical trials, arranged generation and dispersion, multiple practices need to be well organised and conducted at once. These problems contribute to a build-up of savings and a lifting of monetary opportunities. Delayed immunisation will lead to the episodes of amassing death and dreariness, as defined by the 2013/14 Western African Ebola flag that killed more than 11,000 people at the expense of over $\$ 53$ B. Appallingly, the antibody was advanced and was then proved feasible in Ebola protection which could have related to episode management (35).

Tragically, the 2003 SARS plague has just ended a phase of progression of antibodies. It is frustrating that at that time, subsidising organisations moved shops that were dedicated to advance immunisations, disturbed suppliers and re-established other immunisation programs. The 2017 merger of pesticide readiness creative initiatives (CEPI) was planned to resolve previous disappointments in an effort to build smoother reactions to irresistible infection hazards in order to ensure the progression of immunisation and the early reaction of scourges (36).

Different characteristics of phases of invention One technique was used for solving street squares in order to further advance immunisation (37). Immunisations approved for individuals typically include live constriction infections (for example, measles, mumps, rubella), protein or polysaccharide conjugated subunits (protein: acellular pertussis; hepatitis $\mathrm{B}$; pneumococcus, meningococcus), polysaccharide conjugated with viruses. A collection of unused technological platforms was developed in the last decade, combining anticorrosive (DNA and RNA) nuclear antibodies and viral vectors as well as recombinant proteins.

\section{DEVELOPING COVID-19 VACCINES}

\section{Stages of Vaccine Development}

Every modern vaccine is conducted following a strict Investigate and Advancement convention that has to be taken rapidly and recently completed and has been approved (Figure 3). The rules on improving anticuerpos are more restrictive than the rules on drug creation, which are relevant in clinical evaluation, are provided by administrative specialists directly WHO, US Sedate \& Diet Organisations, the European Solutions Organisation and national specialists from various countries (38). This should be apparent because antimicrobials are used globally, have tremendous demographic potential and are distributed to stable communities, including infants, elderly and pregnant moms.

The improvement of anticorps takes place following an evolved design which is widely separated into exploratory, preclinical, therapeutic and post-marketing processes. The clinical organisation, to particular processes I, II and III, is split into 3 phases. The clinical organisation is recently needed for two administrative authorisations, "Clinical trial authorisation," which provide for "first-in-human" research and "biolocation / authorisation" to facilitate immunisation following fruitful clinical trials (Table 1). Two administrative approvals ought to be provided.

\section{A Race against Time}

Due to certain truths, almost antibody progress is dazzling. Immunisation from exploratory agreements to exhibiting can be a long task that typically requires 5 to $10 \mathrm{y}$. For COVID-19, the usage of innovative technologies to establish candidate antibody (preclinical arrangements) and swift permission by regulatory institutions for clinical trials has greatly compressed this time. This period of immunisation. It took $42 \mathrm{~d}$ from community monitoring of the infection to form an unexploited immunisation period (mRNA-1273) at the cGMP office of Moderna Inc. (the American biotech corporation located in Cambridge, Massachusetts). It would have taken typically more than two long stages to produce such a vaccine without stage invention.

Under either event, the "rate-limiting" and "temporary" clinical studies after a special convention. In addition, the examiners investigate innovative knowledge gathering techniques in order to react to the general issue. Many engineers perform simultaneous clinical testing (stage I-II) to reduce the approval period. Some of them also started gathering adequacy data from Step II (IIb) itself. In COVID-19, an analysis of the opportunity for a successful voluntary officer is severely challenged to determine if challenge spokesmen are moral. In the off-price situation, efficient evidence on the COVID-19 antibody could be accessible within a couple of weeks instead of a long period. In either scenario, without proof of immunogenicity, success and efficacy of COVID-19 vaccine, it would be risky.

\section{Success Rate}

The moment that requires to be considered is the pace of development of immunisation from authorisation for clinical studies to authorise. In the years 2000-2010 period, the rate was consistently $<10 \%$. One of the 37 antibodies developed for Ebola, as one was approved depending on viability and protection within the step II research, is a 2015 study that indicates only $20 \%$ of therapeutic immunisation tests vary from stage I to licence. In the immunising scene of COVID-19 examiners introduced untapped, nuclear corrosive technology-based vaccines. Such advancement in immunisation against irresistible diseases is no scientific procedure, and specialists recognise the effective rate of an approved urgent immunisation of $5 \%$ (39). 


\section{Costs}

It must be considered, too, that progression to immunisation will entail a high risk. Apart from a rivalry between other large suppliers of antibodies, it has been considered to be worth more than1 M USD to establish a single untreated immunisation against an irresistible infection. The Figure 1 includes deserted antibodies in readiness for improvement. A few institutional and nongovernmental organisations here have upheld the teaching of sufficient stores in the light of the human tragedy and worldwide extinction. Coalition for Scourge Preparation Advances (CEPI) will be an organisation that takes the donations of free investigative projects to build antibodies to evolving unstoppable pathogens through transparent, private, caritative and respectful organisations in society. The US Government decided to offer 483 M USD to Moderna Inc. to produce the vaccine COVID-19.61 The Canadian Government started the CAD 1.3 B in improving immunisation financing to investigate the advancement and improve it is now using in its 2022.62 stage technology - a Gamechanger breakthrough. Conventional biotechnology techniques have been used to generate the nominee antibodies throughout the year. As it took between 2 and $5 \mathrm{y}$ for a model anticorps to be developed and some vaccinations were prohibited. The accessibility of bleedingedge investigations into offices was essential for the enticing expert to be included, which could be conceived of as it was in just a few testing facilities worldwide.

Stage advancement provides a couple of areas of interest in the production of antibodies that involve mechanisation, speed, ability to generate certain model antibodies in a single sense, productivity and simple formation, including complicated mRNA antibodies. As the candidate vaccine may be developed within days instead of a long period, stage technology has been described as a single play changer while combating the scourges or pandemics induced by modern times. The antibody produced by the mRNA is appropriate and is created by the stage invention. In general, eight kinds of plans were evaluated for the development of COVID 19 antibodies under four large bunches (Table 2).

Every immunisation strategy has a delicate framework, priorities and impairments in immunogenicity, protection, user-friendliness and efficacy (Figure 1) (40) The mechanism through which living infection is carried by a creature or human cells before its genome changes, and it cannot trigger illness is produced through living attenuated immunisation. The infection at the end of the week imitates a normally contaminating condition that triggers a heavy T-cell and B-cell healthy, permanent reaction. This anticorps are perfect for individuals to become disrespectful to the population and piece epidemic spread. However, there is a slight risk of a transition to destructive consequences and the disease occurrence. Other than this, the city wants a cold chain to distribute these Anticorps. These vaccinations are demonstrated by GCB, PMD, MMR, rotavirus, polyomyelitis (OVV), etc. Multiple immunisation is not accessible. Formaldehyde or warm inactivated vaccines are treated and, until the virus is slaughtered, those vaccines are healthy and do not contribute to an infection.

In any event, these immunisations should not duplicate, induce an immune response suboptimally and requires

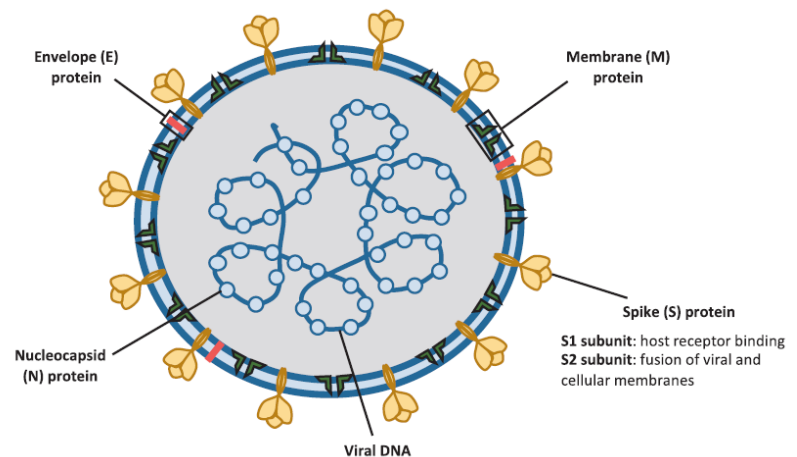

Figure 1. Schematic of the structure of SARS-CoV-2 (41)

rehazed dosages and adjuvants to boost insensitivity. In such vaccines, ADE has been detailed and to prevent this, the arrangement of epitopes on the antigen surface should be controlled during inactivation. Poliomyelitis (IPV), HAV, rabies, etc., are illustrations of such anticorps. The new anticorrosives made available by cutting-edge advances are the nucleic corrosive antibodies. Incorporations of DNA that encode a pathogen into plasmid DNA are the foundation for DNA immunisation. RNA antibodies use SARS-CoV-2 lipid-coated mRNA that transmits Spike protein. The proteins are displayed from CD $+8 \mathrm{~T}$ cells BY MHC course I and activating a solid $\mathrm{T}$ cell response. These anticörpers are healthy, simple to produce by stage advancement, and are likely to improve immunisations for the future. No nucleic acid vaccines are presently licenced in clinical practice.

Recombinant vector infection vaccines are developed by the invention of recombinant DNA. The DNA is integrated into the cells and then filtered (42). In the process of the vaccine, the vector duplicates and alongside, the embedded DNA is communicated and generated, which produces a robust $\mathrm{T}$ cell and $\mathrm{B}$ cell-resilient reaction. It often involves the usage of DNA as microbes or infection vector. Microscopic species like E can be vectors. Coli, Adenovirus or poxvirus diseases. Coli. Standard vector anti-corps examples are HBV, HPV, Hib and Meningococcus. Antibodies consisting of antigenic decontaminated peptides from pathogens such as SARSCoV-2 Spike Protein are healthy to use. Such antigen is expressed directly at the MCH Lecture II and does not routinely induce a significant cytotoxic $\mathrm{T}$ cell reaction. These vaccines need revived dose and tolerance adjuvants. Virus-like particles are composed of inherited tissue free purge infection particles. These vaccinations are healthy and immunogenic, which are difficult to produce in any event.

\section{TREATMENT OPTIONS}

Clinical studies are performed in which possible antiviral therapeutic goals, such as the restriction of the genomically replicable viral proteins, or the blockage of the viral transit through human cells, are examined. There are numerous plausible strategies for Fighting COVID-19 pharmacologically: small-molecule medicines, antimicrobials, oligonucleotides, peptides and monoclonal anticorps. Medicines that can function on the coronavirus may be classified by viral proteins or chemicals appropriately by viral auxiliary proteins, limiting the 
automatic assembly or preventing infection by binding to ACCE2, by preventing RNA replication and amalgamating by preventing and encourages reconstruction. The $\mathrm{S}$ protein may be a fundamental aim for advancing immunisation (43). In both situations, few drugs are produced to attack proteins from the film, atomic capsid or envelope. Figure 2 demonstrates a conspiracy of SARS-CoV-2 and some of its atomic protein goals (44). Such medications which are currently used to prescribe COVID-19 are recycled medicines which are typically prescribed to people who have other viral problems, such as anti-HIV operators or medicines that are used for the administration of flu. As of late, the high-resolution architectures of the complete ACE2 were reported in Yan and his colleagues. The authors recommended that connexions between the ACE2 dimer and the two $\mathrm{S}$ protein trimmers be present at the same time (45). The use of specific medicines to inhibit viral attachment and passage or use large-speed antiviral medicines will either ensure the use of persuasive pharmacohilfe-based approaches to SARSCoV-2.
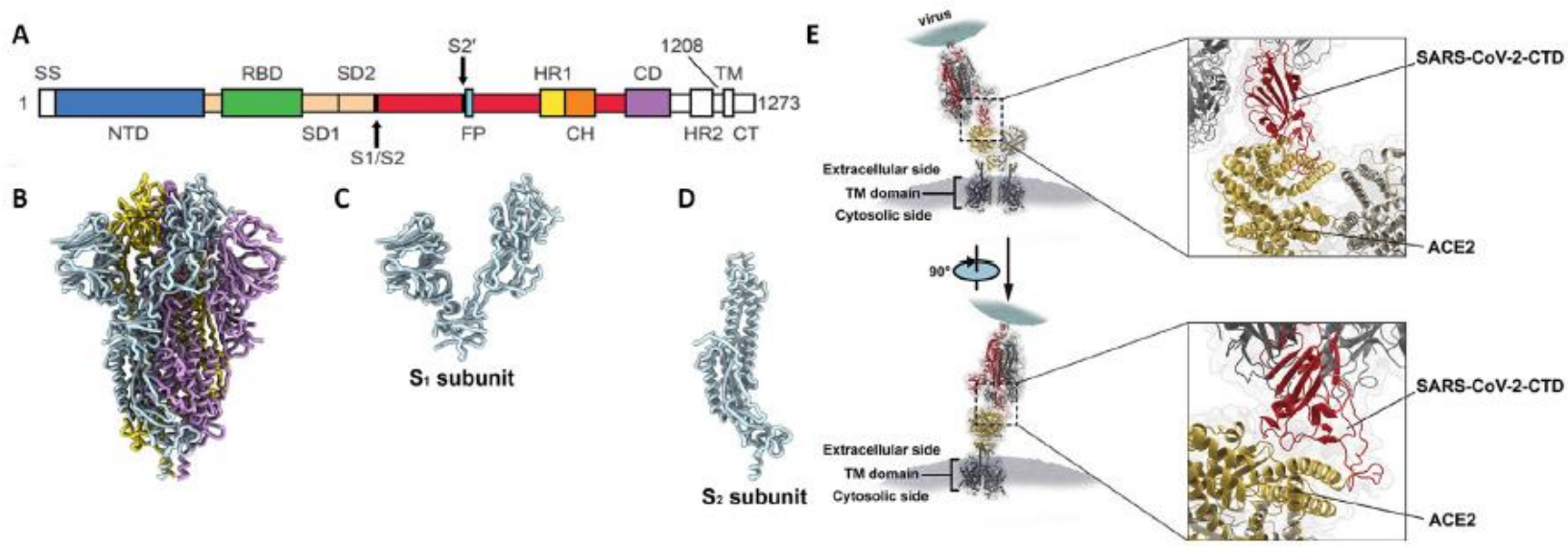

Figure 2. Structure of SARS-CoV-2 S in the pre-fusion conformation and the genome. Along with the crystal structure of the C-terminal domain of SARS-CoV-2 (SARS-CoV-2-CTD) S protein in complex with human ACE2. (A) Schematic of SARS-CoV-2 S primary structure colored by domain. SS: signal sequence, S2_: S2_protease cleavage site, FP: fusion peptide, HR1: heptad repeat 1, CH: central helix, CD: connector domain, HR2: heptad repeat 2, TM: transmembrane domain, CT: cytoplasmic tail. Arrows denote protease cleavage sites. (B) Ribbon diagrams of the SARS-CoV-2 S ectodomain cryoEM structures. (C) The SARS-CoV-2 S1 subunits. (D) The SARS-CoV-2 S2 subunits. (E) A hACE2-binding mode of SARS-CoV-2 (46)

The pharmacotherapeutic alternatives may be formulated as peptide inhibitors, monoclonal anti-SARS-CoV-2, protease inhibitors, certain antipalarial solutions and antiACE2 monoclonal anticorps. Confrontational studies are published nearly scientifically adequate for some of the test drugs used for COVID-19 administration. Because of the present elevated morbidity and death, research studies are not performed correctly, and most of the medications are only for humanitarian purposes. Around the same period, clinical studies on each of these medications are being performed, but the trials are yet to commence. Figure 3 (47) displays a sterilising SARS-CoV-2 Development cycle and restorative goals. During a wide range of the examinations, Monteil and colleagues demonstrated in vitro that humans could reduce viral development by recombinant dissolvable ACE2 (hrsACE2).

The creative companies have also detailed the fact that early hrsACE2 can totally block contamination of kidney and human blood vessel organoids (49). The treatment of COVID-19 is suggested for re-desivir, favipiravir and chloroquine. Ritonavir / lopinavir, alone or used with monoclonal antibodies and intergalactic-b, is a recurring medicines that may be useful (50). In vitro and in creature studies, lopinavir (LPV) was found to be movement square coronavirus protease. Analysts combine ritonavir periodically with lopinavir to increase plasma halving through cytochrome P450 suppressions (51). Protease inhibitors target $3 \mathrm{C}$ proteases and papain-like proteases in coronaviruses. The COVID-19 randomised controlled test persisted in dyspnea and desaturation in China and recommended that lopinavir / ritonavir treatment be comparable to normal care for clinical progression.

However, this combination treatment was terminated early since side effects like loose bowels, queasiness and hepatotoxicity (51). Leronlimab might be a 5 adversary and a humanised monoclonal counter acting agent for $\mathrm{C}-\mathrm{C}$

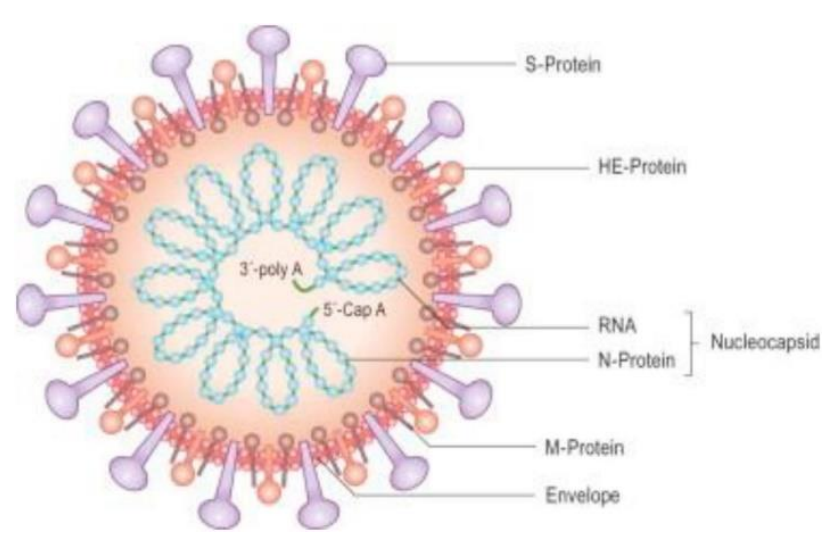

Figure 3. Skeleton of coronavirus; inside and outside morphology (48) 
chemokine receptor, whereas Galidesivir may be a nuclear RNA polymerase blocker. Analysts were analyse the efficacy of the application of COVID-19 through the two medications (52). The SARS-CoV-2 is linked to the alveolar epithelium and therefore both the versatile and the natural resistant frame acts, counting interleukin 6 (IL-6) as an expanding cytokine discharge. Tocilizumab (TZM) is a monoclonal counter acting agent for anti-IL- 6 receptors. The sedate attaches to both the membrane-bound and the dissolvable IL-6 (mIL-6R and sIL-6R) receptors and squares mIL-6R and the flagmediated sIL-6R, respectively. A number of patients with severe VOC-19 had cytokine discharge (CRS) archived, and a few passes were taken by CRS (53).

IL-6 is a key part of the CRS, so IL-6R TZM is useful for administering the "cytokine storm" seen in COVID-19 patients. IL-6 is also a vital part of the CRS system. "Cytokine Storm" is distinguished by a raised level in particularly cytokines inflammatory markers (54). Actually, TZM is being used as a SARS-CoV-2 inquiry operator. CR3022 can be a monoclonal counter acting agent calmed out of SARS, and the compound is captured by the quality of IGHD3-10, IGHV5-51 and IGKV4-1, IGKY2 (light56 chain) CR3022 can be a monoclonal counteracting agent. Although a highly moderated area in the epitome was detailed, the interatomic CR3022 Fab with SARS-CoV RBD is more notable than the SARSCoV-2 RBD. It was assumed to be possible, from the nonconserved build-ups in the epitope, to determine incongruities within the bonds between SARS-CoV-2 and CR3022 (SARs-CoV-2). The SARS-CoV-2 Spike Protein RBD is attached to the CR3022 (55).

This can happen since the epitope of the antimicrobial and the ACE2 receptor binding topic have no cover. CR302, either alone or in pairs with other neutralising antibodies, can be valuable for the management of COVID-19. However, clinical adequacy and security ponder ought to be carried out sometime recently utilising these drugs for people enduring from COVID-19 (50). Remdesivir (RDV) may be a 10-cyano-substituted adenosine analogue, a phosphoramidate prodrug and an RNAdependent RNA polymerase (RdRp) blocker that acts by repressing the synthesis of viral nucleic corrosive by means of bond arrangement with the dynamic location of RdRp (56). RdRp could be a protease interceding in the centre of the roadway structure for the replication of RNA (57). The shirting of the editing of SRS-CoV-2 exoribonuclease is another tool of the RDV. The viral RNA is prevented prematurely as a consequence of these impacts.

Remdesevir, originally developed to cure and afterwards dropped Ebola infection, is used as a research drug for patients with COVID-19. In addition, Remdesevir has antiviral effects on other RNA infections, for example, MERS-CoV or SARS-CoV (58). In reality, while widespread intelligent and cardiovascular toxicity drugs have not, after a single patient has stacked dose (among 175 add up to) after Remdesivir usage in the Ebola epidemic, hypotensions with subsequent cardiac catch were not reported (59). The CC chemokin receptor 5 (CCR5) competitor may be Leronlimab (PRO140) as well as the investigational, unused COVID medication. CCR5 is categorised into many types of biological structure, e.g. tumour intrusion, metastases, HIV-1 joining CD4 $\mu \mathrm{T}$ and nonalcoholic steatohepatitis pathogenesis (NASH) (60).
Favipiravir is another compound used for COVID-19 administration.

Although the basic component of SARSCoV-2 behaviour cannot be fully clarified, it is easily established as a substratum for RNA viral polymerase after a phosphoribosylated transformation (61). The viral genomic RNA medicines mix together as a chain remover. An efficient way of finding COVID-19 medicines is to assess whether current antiviral medications are effective (62). Favipiravir is a verbal pyrazinecarboxamide subsidiary (FPV) and guanine analogue that is robusted and precisely carries the RNA dependent RNA polymerase (RdRp) of RNA (63). Favipiravir is a subsidiary of RNA pyrazinecarboxamide (FPV). It appeared late that FPV in Vero E6 cells as a medication would considerably delay the disease SARS-CoV-2 (62). Along with antiviral solutions, hydroxychloroquine and chloroquine were used to create research options for pneumonia linked to COVID-19 pharmacotherapy (64).

Chloroquine is suspected to discourage viral matter from attaching to the cell surface receiver and therefore from preventing COVID-19 viral pre-entry. The medication operates on quinone reductase 2 , ultimately bound to 2epimerase UDP-N-acetylic-glucosamine (UNEs). A sialic biosynthesis catalyse. Sialic acids are fundamental compounds of cell transmembrane protein sugar particles which are necessary for ligand recognition. Closed ACE2 glycosylation has culminated in the strong effects of chloroquine on SARSCoV-1 in vitro. The endosomemediated entry of SARS CoV infections may be too interspersed with $\mathrm{pH}$-dependent chloroquine. In mixing endosomal and viral layers for the cytosolic conveyance of the SARS-CoV-1 genome, acidic pH is essential (65).

The virus reaches into the lysosome without an anti-viral pharmaceutical, where both the enzyme and moo $\mathrm{pH}$ clamps the viral molecule and activates replicant proteins alongside the RNA. The portion of chloroquine-antiviral activity is hypothesised to contribute to the rapid increase of endosomal $\mathrm{pH}$, endocytose anticipation and destructive combination of endosome viruses (66). Chloroquine and hydroxychloroquine (67) antiviral elements. In another study, blood plasma was transfused into people with SARS-CoV-2 disease with positive and swift development in COVID-19 patients and pushed them to recovery (47). The FDA has affirmed that Ivermectin is a broad spectrum anti-parasitary operator. Caly et al. have tached Vero / hSLAM cells with SARS-CoV-2 disconnect Australia/ VIC01/2020 following the extension of ivermectin to assess the antiviral movement of ivermectin to SARS-CoV2 (40). This sedate has declined viral RNA up to 5000overlapping after 48 hours of SARS-CoV-2 disease (51).

\section{VACCINE CANDIDATES}

Figure 5 depicts the spread of the pandemic scenario globally. As of 1 December of 2020, the COVID-19 prophylaxis was propagated by 124 candidate antibodies. For these, ten individual clinical trial applicants in adult patients have reached step 1 , mixed stage $1 / 2$ or stage 2 (69). Several antibodies against SARS-CoV-2 are being planned and generated using different methodologies. Figure 6 indicates a schematic stream of COVID-19 transmission and the job sources used in SARS-CoV-2 vaccine candidate preparation (70). In the management of 
inactivated virus antibody chemical and physical methods including formaldehyde, ultra-violet light, or bpropiolactone may be used. A reduced pathogenetic infection, such as improved anti-inflammatory cytokine concentration, lower neutrophil dilution and less lung damage compared to wild SARS-CoV-2 (71) can be described in the distinction. The surface-exposed spike (S) glycoprotein is the coordinate of most anticorruptions.

Different examiners employed strategies of the immunisation programme focused on the usage of official $\mathrm{S} 1$ space receptor (RBD), full-length $\mathrm{S}$ antigen, virus-like particles (VLP), and DNA or vectors speech. It is presumed that the use of spike protein-based vaccines might contribute to the development of antibodies that decode square viral genome and authoritative receptor. Enhancing an all-inclusive $\mathrm{CoV}$ antibody is feasible as the SARS and MERS CoV T-cell epitopes are identical in nature and can contribute to cross-reactivity. SARS-CoV2 has a tall, genetic resemblance to SARSCoV, such that the cross-reactivity of the SARS-CoV-2 antibody may be shown. Research in both forms of infection with $\mathrm{S}$ proteins found extremely variable accumulations of amino corrosion in the subunit S1. This heterogeneity indicates that SARS-CoV-2 (50) does not have effective consequences with immunisations that contribute to a preventive, resistant reaction against SARS-CoV. On the surface of SARS-CoV-2 the local S protein can be used as a trimmer. Its ectodomain or sub-unit S1 mainly interacts in a monomeric mode in a eukaryote. Kim et al. have a meld of the SARS-CoV-2-S1 and MERSCoV-S1 structures to a 27 amino corrosive foldon segment to synthesise trimeric recombinant codon-optimised sub-unit proteins. The foldon is received from the $\mathrm{C}$-terminal region and can be framed by trimmers of the T4 fibrite bacteriophagus. TLR4 or TLR5 are collectively known as RS09 or flagellin. These resistant protein immunisation stimulants were included. Too many were consolidated to help metal-chelating partiality refining (72), the six histidine tags and an arrangement for the cleavage of Tobacco Carve Infection (TEV) was used. In the context of the examiners (73), a transportation carrier (pAd / MERS-S1f) was used.

It has been shown that adenoviral antibody conveyed by a SARS-CoV-S1 and MERS-S1 has been rendered more viable than a full-length $S 1$, which indicates that the immunogenic subunit might be an ideal antibody. Carboxymethyl cellulose was employed in the manufacturing phase to prepare dissolvable micro-edles with the MERS-S1, MERS-S1fRS09, MERS-S1fFliC or with the SARS-CoV-2-S1fRS09 proteins. Micromolding was used in the planning of $10 \times 10$ polydimethylsiloxane (PDMS) obelisk-shaped microneedles. The developers then arranged immunisations using a two-step spin-drying process for CMC-based MNArMERS-S1f, MNArMERS1fRS09, MNA-rMERS-S1ffliC, MNArSARSCoV-2-S1 or MNA-rSARst-CoV-2-S1fRS09. In comparison to intracutaneous organisations of arranged dissolving miniature needles, the preclinical immunogenicity of MERS-CoV immunisations treated subcutaneously via routine hypodermic needles.

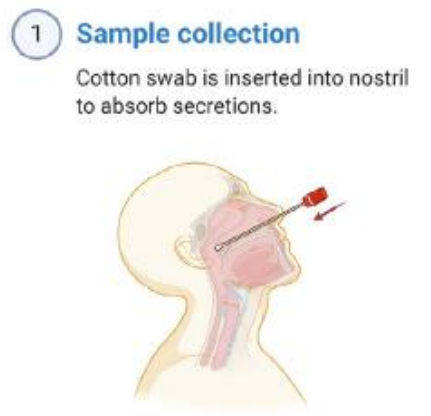

(2)

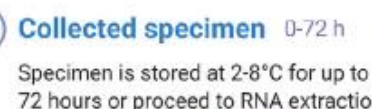
72 hours or proceed to RNA extraction.

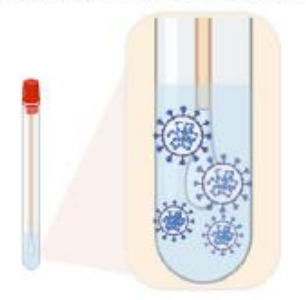

(3) RNA extraction $\sim 45 \mathrm{~min}$

Purified RNA is extracted from deactivated virus.

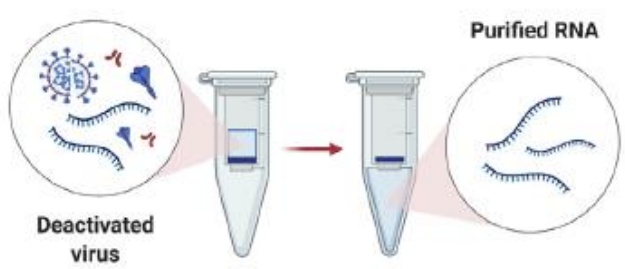

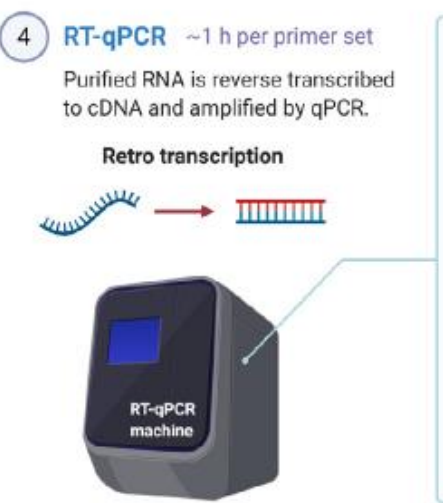
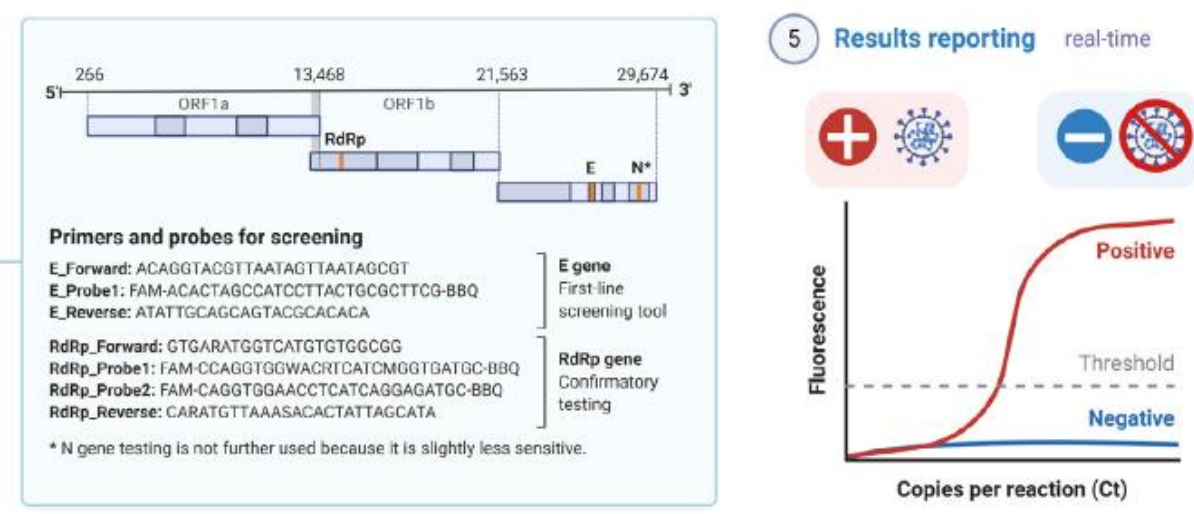

Figure 4. COVID-19 diagnostic test by RT-PCR. First, a cotton swab is deployed to collect the secretion sample from the patient's nose or throat. The virus particles in the sample are then deactivated along with the separation of RNA strands. Then, the purified RNA strands are copied by utilizing reverse transcription and amplified by RT-PCR to detect the presence of virus-specific gene sequences (68) 


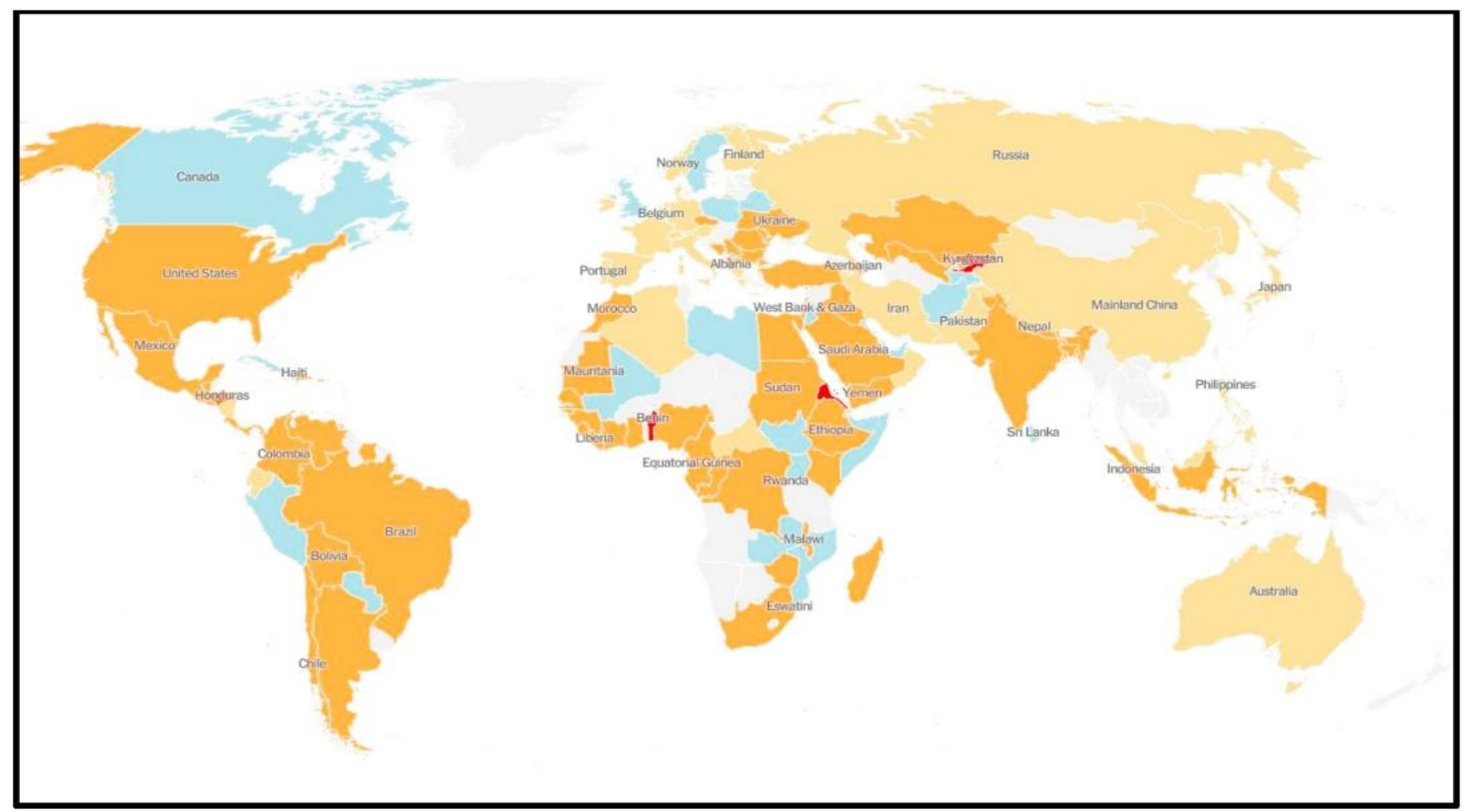

Figure 5. Map of spread COVID-19 global outbreak as of 31 Jan 2021. Blue colour indicates a decrease in coronavirus cases where orange and red colour indicates the increasing number of coronavirus cases (20)

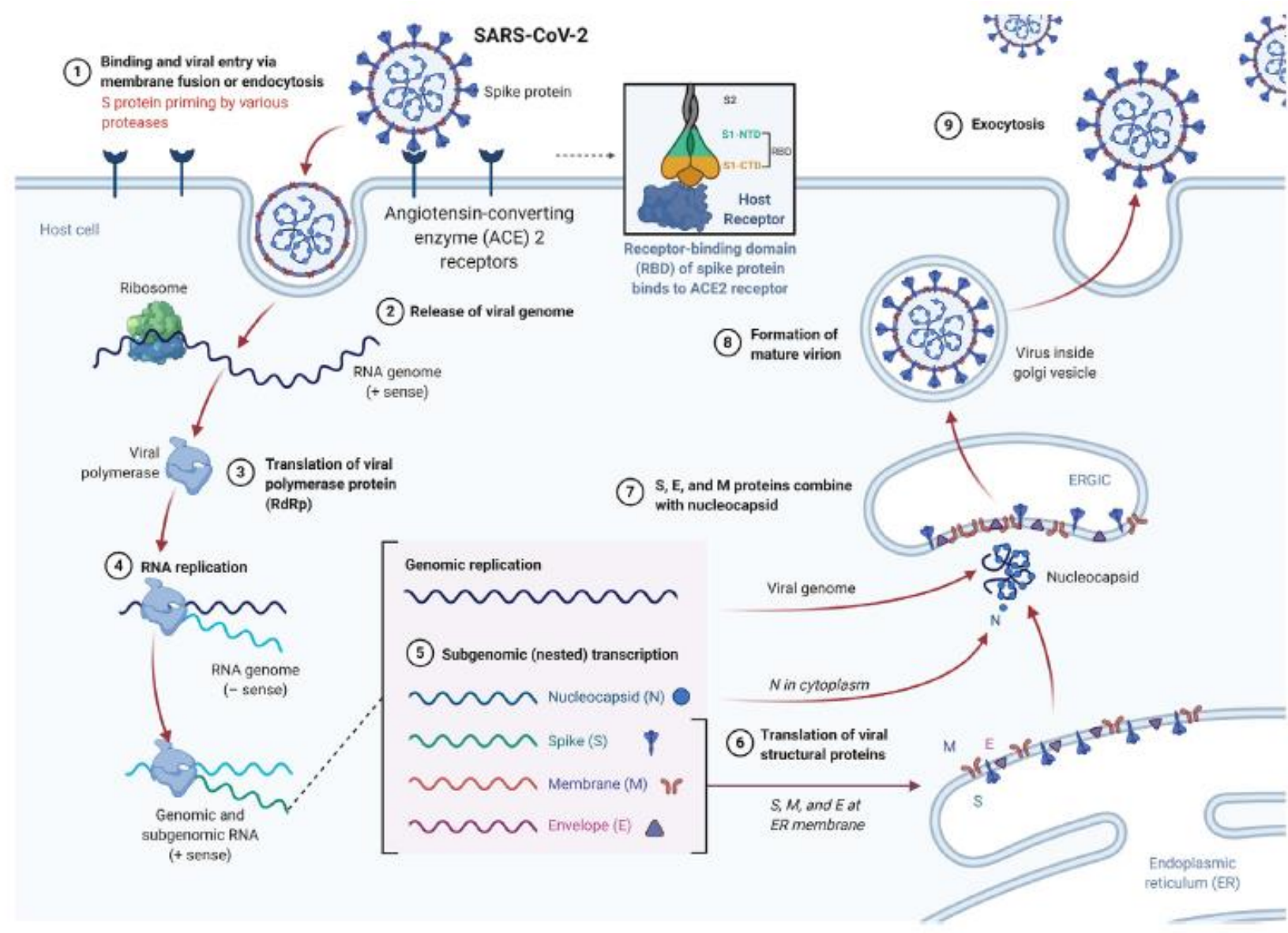

Figure 6. The possible viral entry and replication mechanism of SARS-CoV-2. When the S protein of SARS-CoV-2 binds to the cellular receptor ACE2, it begins its life cycle. After the receptor is bound, the conformational change of the $S$ protein helps the viral envelope to fuse with the cell membrane through the endosome pathway. Then, SARS-CoV-2 releases the RNA into the host cell. Genomic RNA is translated into viral replicase polyproteins ppla and 1ab, which are then cleaved into small products by viral proteases. The polymerase generates a series of subgenomic mRNAs through discontinuous transcription, which is ultimately translated into related viral proteins. Viral proteins and genomic RNA are subsequently assembled into virions in the ER and Golgi, and then transported through vesicles and released from the cells. ERGIC, ER-Golgi intermediate compartment (68) 
Antibodies to immunoglobulin $\mathrm{G}$ have been evaluated and neutralised in pathogens. Significantly, the antibodies conveyed by microneedles of the SARS-CoV-2 S1 subunit were observed after 14 days of inoculation (72) with good healthy reactions. Because of its unpainful and painlessness, microneedles are beneficial. The most common application of peptide Antibodies is to synthesise T-cell and B-cell epitopes that are immuno-dominant. Immunogens can be produced by binding a T-cell epitope to a destination atom's B-cell epitope. T-cell epitopes are small fragments of a peptide (8e20 amino acids), while Bcell epitopes are large and protein-limited. In addition, the implication may be used to control peptide-based vaccinations. The JI et al. used Non-replicating antigens SARSCoV2, antigen-specific cells (the so-called "Icells") as moderation and immunogenic antigen vectors (74).

The protected system will identify viral proteins that are productively insusceptible by using illuminated cells as a carrier of SARS-CoV-2 antigens. The organisation named Generx uses a co-ordinated peptide method for biotechnology. The business has developed a SARS-CoV2 peptide antibody that uses ingenious viral peptides as immune mechanisms and uses the secure and special IiKey Healthy Structure (75). Another company (Novavax) has also developed NVX-CoV2373 as a co-ordinated SARS-CoV-2 vaccine candidate. The company's restrictive nanopart platforme (Matrix-M) typically contains a steady prefusion protein, which enhances the resistance to resistant reactions and enhances the blood concentration of antibodies that neutralise. While mRNAs and DNA vaccines are illustrated and converted into clinical trials, the administrative authorities for human usage should still accept these kinds of anticorporeal diseases (71).

The SARS-CoV-2 DNA antibody can be identified and communicated within human cells as an antigenic protein. This technique is valuable because it reflects live vaccinations from the viewpoint of facilitated reaction. Moreover, it is reasonably effective to schedule DNA vaccines, and to some extent, protection problems (as opposed to live vaccinations) are minimised (76). The large-scale, highly distilled DNA anticörpers can be generated and are compatible with proteins and other biopolymers (77). However, for individuals, DNA anticorps were not verified. Any firms are researching SARS-CoV-2 DNA antibodies, and Inovio Pharmaceuticals is actually running clinical trials for the immunisation of the SARS-CoV-2. For SARS-CoV-2 vaccine candidates, certain vectors are also being explored. The SARS-CoV-2 immunisation (78) is now being carried out by the Oxford Antibody Gather in conjunction with the Oxford Jenner Institute (ChAdOx1). In India, the Oxford/AstraZeneca coronavirus and the Covaxin domestically produced vaccine has been granted emergency authorisation and are announcing the launch of one of the world's largest immunisation drives Covid-19. During a Sunday press conference, India's General Drug Controller said the decision to approve the Oxford vaccine and the Covaxin, both developed from and partly funded by the government by the Indian company Bharat Biotech, came after 'careful review' of the results. Indeed, it has made India the second country to allow the use, after the UK given the green of the Oxford/Astra Zeneca vaccine known as Covishield, in India.
Viral vector-based immunisations may be constructed and used without an adjuvant, but antigens with neutralising epitopes are needed for the specifics of these anticorps. The combination of adenovirus vectors is normally safe and can cause strong, large and safe mobile and humoral reactions (53). Owing to the large dimensions used by the genome in use kilobases (79), adenovirus vector production is very challenging. Furthermore, there are insufficient areas of confinement. More frequently than not, ordinary recombination-based methods are used, with certain examiners relying on the unusual local boundaries, but such techniques are time-consuming and difficult to monitor. Some designers used the Gibson ligament which permits examiners, through the composite effects of a DNA polymerase, exonuclease and a DNA ligase, to gather a couple of covering DNA particles (79).

The researchers first broke down the DNA components and obtained a specially tempered single-stranded DNA overhang and subsequently covalently combined. The usage of RNA immunisation for the administration of COVID-19 is greatly fascinated. Courier RNA (mRNA) speaks to the half-way point of the understanding in the cytoplasm of protein-encoding DNA and protein biosynthesis. There is a clear analysis as an antibody of two main forms of RNA: virally defined RNA self-amplification and mRNA not replicate. The RNAs normally encode themselves as the antigen and the specified viral replication appliance, while traditional mRNAs encode fascinated antigen with 50 and 30 untranslated areas (UTRs). MRNAs are extremely potent, and they can easily be produced, rendered with a moo and handled securely in comparison with traditional antibodies (80).

The specificity of antigen plans is important for having both relaxed and imperative reactions to the production of hazards of pandemics and scourges (81). Usage of mRNA for anticorps detail has certain advantages compared to live, slaughtered pathogens, sub-units and vaccines dependent on DNA. mRNAis a non-integrative and noninfectious level, so insertional mutagenesis or contamination is not potentially dangerous. Many mRNAs may also be conveyed in a single antibody, encoding a few antigens (82). Moderna has established the candidate for antibody (mRNA-1273) which forms part of the amalgamation of SARS-CoV-2 $\mathrm{S}$ protein perfusionstabilised enforcement. Clinical studies are actually being performed for immunisation. An updated non-autoamplifying immunisation with an mRNA containing an open perusal frame (ORF) was developed by Richner and his colleagues at the latter stage. The antigen is encoded by the ORF (83).

The designers arranged DNA-dependent RNA translation for the mRNA in vitro through T7 polymerase where 1methylpseudoUTP was replaced by the Uridine-50tryphosphate. There was used a linearised DNA format with a poly-A tail comprising 50 and 30 non-translated areas (UTRs). The designers used the Sadenosylmethionine (SAM), a methylated capsulated RNA (cap 0), which was engineered for a cap 1 structure to increase mRNA interpretation performance. Two important approaches to strengthen COVID-19 antibodies are in place: the choice of antigens and the choice of a production firm. The progression of COVID-19 vaccines is currently investigated for the lipid nanoparticles. The 
writing was highlighted with the Lipid nanoparticle (LNP) transport of modified mRNA (82).

In a fascinating study, Geall and associates have clarified in-depth that the NPL transmission of a $9 \mathrm{~kb}$ RNA that amplifies itself totally enhances immunogenicity compared with the exposed RNA organisation. In order initially, to encode the self-amplifying RNAs, the developers created DNA plasmids. The plasmids were opened, and the DNA was linearised by the containment method. The MEGAscript T7 packs were used for the interpretation of the linearised RNA formats, and lithium chloride $(\mathrm{LiCl})$ precipity was used to decontaminate them. In these lines, the RNA was capped and washed by $\mathrm{LiCl}$ precipitation with a vaccine capping system. The LNPs that include lipid compounds, such as 1, PEG-DMG 2000 , $\mathrm{N}, \quad \mathrm{N}$, NDimethyl- 2,3-bis ([9Z,12Z]-octadeca-9,12dienyloxy]propan-1-amine [DLinDMA], 2, Dia-Dia-SnGlycer-3-phasphocholine), and Cholesterol (84) were produced via a controlled ethanol-weakening technique.

The latest period, Baruah et al. used an immunoinformatic method in the spike SARS-CoV-2 protein to pinpoint $B$ cells and cytotoxic T lymphocytes (CTLs). In addition, the developers used atomic elements to analyse the connexions between the main Learning I (MHC) and CTL epitopes. The investigators found three consecutive B cell epitopes, five CTL epitopes and five $\mathrm{S}$ cell epitopes. It was discerned that a few instruments such as salt bridge grapples and hydrogen bonds were used in the CTL epitope tie to MHC course I to demonstrate how these epitopes may be used to mount a stable reaction (85). In another respect, the $\mathrm{T}$-cell and B-cell epitopes, both SARS-CoV-2 and SARS-CoV, were recognised by Ahmed and colleagues. About $82 \%$ of 229 epitopes were limited epitopes of the MHC Course I (86).

102 of the 229 epitopes of the $\mathrm{N}$ or $\mathrm{S}$ protein had been organised. The SARS-CoV receptor binding theme has been thoroughly defined by three groupings (QPYRVVLSF, GYQPyRVVVL and PYRVVVLSF), which is known to be an indispensable virus for cells to join the have cells. The developers studied the MHC alleles and recommended certain epitopes of a relationship in the T-cell epitopes that could give a wide safe reaction in China and across all (86). In another analysis, the SARS-CoV-2 spike defence for the immunogenic epitope plan was defined by Bhattacharya et al. The developers have selected 13 MHC-I epitopes and 3 MHC-II antigenic epitopes. The developers had used the Secure Epitope Database server to examine the $S$ protein and observed that 34 straight B-cell epitopes had T-cell epitopes competent to function with the MHC-I, and MHCII particles had been analysed by the SARS-CoV-2 arrangements. The designers found $8 \mathrm{MHC}-\mathrm{II}$ epitopes and 29 MHC-I epitopes (87). Functional vaccination is still being tested. The Joint States of America investigates a linguistic polio antibody, while in the Netherlands, Australia, and South Africa, 3 multicenter, randomised, controlled studies are ongoing. In Egypt (69), a measles antibody assay for COVID-19 prophylaxis was recruited.

\section{VACCINATION STRATEGIES}

Many attempts were coordinated to further the immunisations of COVID-19 to deny the common usage of the S-protein SARS-CoV-2 by most of the candidates in the development of immunisations (50). From 2 July 2020,
158 antibody candidates were included in the worldwide SARS-CoV-2 scene, 135 of them being preclinically or exploratorily enhanced. Right now, a number of stage I / II clinical trials are being carried out on mRNA-11273 (Moderna), Ad5-nCoV (CanSino Biologicals), INO-4800 (Inovio, Inc.), LV-SMENP-DC, ShinzenGeno-Immune Coordinated Therapeutic (APC) and ChAdOx1 (Oxford College) (88). Sub-unit antigen, virus-like sections (VLP), viral vector (such as duplicative and nonduplicating) DNA, RNA, nanoparticles and others are used in vaccines in the conduit. Antibody Advancement Analysts are currently open (89). In comparison to the epitope with identifiable data of the antibody candidates SARS-CoV-2, an immunoinformatics method is used. The extraordinary cytoto-toxic T cell and B cell epitopes are distinguishable inside viral proteins (85).

\section{Protein Sub-Unit Vaccine}

Subunit immunisation is focused on engineered peptides or recombinant antigenic proteins that are important to strengthening a healthy and/or long-lasting response to the protective (90). The antibody, though, is a mooimmunogenic antibody and requires an adjuvant's assistant bolt for the production of resistant vaccine-induced reactions. The bio-half-life of an antigenic substance can be improved, or the immunomodulatory cytokine response can be increased. The extension of an adjuvant also affects the direction in which protein subunit antibody deficiencies are resolved (91). In order to deter the pathogen, the $S$ antibody of SARS-CoV-2 is the key suitable antigen for neutralising antibodies. Two sub-units are found in the $S$ Protein. The S1 subunit has the spaces FP, HR 1, \& 2 and RBM (RTD, RBD and RBM). By using the official Sprotein interceded with the HACE2 receptor, the virus reaches the cell by an endocytism. Thus, for the institution of a subunit antibody, the S-Protein and its antigenic sections are the primary targets. $\mathrm{S}$ glycoprotein can be an energetic protein with a pre-fusion, two conformational conditions. In order to secure the epitopes for high illumination efficiency counteracting agents reactions (92), the antigen then has to retain its surface chemical and profile of the first pre-fused spike protein. In addition, it indicates targeting the veiled RBM as an antigen enhances the neutralising response of the counteracting agent and raises the overall viability of the antibody.

NVX-CoV2373 (Novavax, Inc. Emergent Bio-Solutions) The nano-partisan immunogenic antibody NVX-CoV2373 is focused on the recombinant expression, coronavirus SProtein, steady pre-fusion. The protein has been communicated steadily within the context of Baculovirus (93). The organisation aims to use the Matrix-M adjuvant to enhance the tolerance to the spike protein SARS-CoV2 by accepting elevated levels of antibody neutrality. A single immunisation occurs inside the high degree of antispike protein antibodies that obstruct the authoritative space of the hACE2 recipient, which tend to motivate wild-type SARS-CoV-2 virus-neutralising antibodies (Novavax covid 19 immunisation study, 2020).

Molecular Clamp Stabilised Spike Protein Vaccine Candidate

It is developed in partnership with GSK and Dynavax by the College of Queensland. In order to improve anti corps reaction and reduce the amount needed by the metrics of immunisation (94), the College will have to establish a 
stage adjuvant invention (AS03 Adjuvant Framework). The College has established a safe, recombinant subunit vaccination of viral protein pre-fusion, focused on the invention of Atomic Clamps. This innovation has shown that the development of neutralising anti corps is being undertaken (94).

\section{PittCoVacc (University of Pittsburgh)}

A recombinant SARS-CoV-2 vaccine, based on a MicroNeedle Cluster (MNA), which contains the rSARSCoV-2 S1 and RSARS-CoV-2-S1fRS09 (recombinant immunosubstances) organisations, may be used. In the preclinical experiments two weeks after the mice models, a substantial rise was found in particular antigen antibodies of factual noteworthiness. In addition, following sterilisation with gamma rays, antibody immunogenicity was successfully preserved. In the early stages, the factually interesting titres, which were recently strengthened, further reinforce MNA-SARS-CoV-2 immunisation (72). Their findings have been enhanced.

\section{Triple Antigen Vaccine (Premas Biotech, India)}

It could be a multi-antigenic VLP immunisation model wherein the recombinant spike, film, and envelope protein of SARS-CoV-2 have been co-expressed in a built Saccharomyces cerevisiae expression stage (D-Crypt ${ }^{\mathrm{TM}}$ ). The proteins at that point experience self-assembly as the VLP. The TEM and partnered expository information at the same time outfitted the biophysical characterisation of the VLP. This model has the potential to enter the preclinical trials as an antibody candidate after assist investigates and advancement. Besides, it is thought to be secure and simple to fabricate on a mass scale, in a costeffective way. 2.2. Viral Vectored immunisation prime the cytotoxic T cells (CTL), which eventually leads to the disposal of the infection tainted cells (89).

\section{Viral Vectored Vaccines}

Ad5-nCoV (CanSino Biologics Inc. Beijing Institute of Biotechnology)

It could be a recombinant, replication imperfect adenovirus type-5 vector (Ad5) communicating the recombinant spike protein of SARS-CoV-2. It was arranged by cloning an optimised full-length gene of the $S$ Protein at the side of the plasminogen activator flag peptide quality within the Ad5 vector void of E1 and E3 qualities. The immunisation was developed utilising the Admax framework from the Microbix Biosystem. The stage I clinical trials have set up a positive counteracting agent reaction or sero conversion. A four-fold increment within the RBD and $\mathrm{S}$ protein-specific neutralising antibodies was famous inside 14 days of immunisation and topped at day 28, post-vaccination. Moreover, the CD4 + $\mathrm{T}$ cells and CD8 $+\mathrm{T}$ cells reaction crested at day 14 postvaccination. Be that as it may, the pre-existing anti-Ad5 insusceptibility somewhat constrained both the counteracting agent and the $\mathrm{T}$ cell reactions. The ponder would encourage assessing counteracting agent reaction within the beneficiaries who are between the age of 18 and 60 , and gotten one of three consider dosages, with followup taking put at 3- and 6-months post-vaccination (95).

Coroflu (University of Wisconsin-Madison FluGen Bharat Biotech)

M2SR, a self-limiting form of the flu infection, which is adjusted by addition of the SARS-CoV-2 quality arrangement of the spike protein. Moreover, the antibody communicates the hemagglutinin protein of the flu infection, in this manner actuating safe reaction against both the infections. The M2SR is self-limiting and does not experience replication because it needs the M2 quality. It is able to enter into the cell, in this manner actuating the resistance against the infection. It might be managed intranasally, mirroring the normal course of viral disease. This course enacts a few modes of the resistant framework and has higher immunogenicity as compared to the intramuscular infusions (96).

\section{LV-SMENP-DC (Shenzhen Geno-Immune Medical Institute)}

Dendritic-cell (DC) architecture with the lentiviral vector, which interacts with the retained spaces of the auxiliary proteins of SARS CoV-2, and the protease used by the SMENP minigens is ready for LV-SMENP-DC immunisation. Antigens on antigenic show cells (APCs), which ultimately work Cytotoxico $\mathrm{T}$ cells and establish a stable reaction, are introduced by subcutaneous immunisation of the vaccine.

\section{ChAdOxI (University of Oxford)}

ChAdOx1 recombinant immunisation with codonoptimised S glycoprotein was identified and synthesised at the end of the 5-inches pioneer arrangement with a plasminogen tissue activator (tPA). The amino acid SARSCoV-2 coding (2-1273) and the tPA pioneer were paired together in the plasmid transportation system. This carrier is built to encrypt, together with the tetracycline administrator (TetO) destination and the polyadenylation flag of the bovine growth hormone $(\mathrm{BGH})$, between the recombinant cloning site of Gateway ${ }^{\circledR}$, significant early qualities of human cytomegalovirus (IE CMV). The vector genome of Adenovirus is formed by embedding the SARS CoV-2 S quality into the E1 site of the ChAdOx1 adenovirus genome into the Bacterial Manufactured Chromosome. In the T-Rex 293 HEK (Human Embryonic Kidney 293), the infection was at this stage allowed to double and was filtered by an ultra-centrifugation angle of the $\mathrm{CsCl}$. Intra-muscular inoculated creatures, the nonattention of subgenomic RNA (sgRNA) is indicative of enhanced infection insurability (97). The past experts have proposed that a single shot can be used to respond safely. The antibody is in therapeutic Stage II tests and can be tested in an immense community test.

\section{mRNA Vaccine}

mRNA is an evolving and non-infectious level with almost no possibility of insertional mutagenesis. The nonreplicating RNS is actually being considered, and the virus is self-replicating RNAs. The mRNA's immunogenicity can be reduced, and the soundness of these antibodies can be enhanced. In comparison, anti-vector insusceptibility remains a strategic distance as the mRNA is the negligible genetic vector, causing the organisation of the immunisation to be re-harvested. Due to its adaptability and ability to mimic antigen structure and expression in the course of typical contamination (98), this stage has enabled the fast antibody production programme.

\section{mRNA-1273 (Moderna TX, Inc.)}

It may be a Lipid Nanoparticle (LNP) antibody consisting of processed mRNA, which codes for the full-length pre-fusion, stabilised SARS-CoV-2 spike protein (S). It may inspire a complex antiviral response to an overly S-protein. It is also deemed moderately protected as neither the inactivated 
pathogen nor the live pathogent sub-units are composed of it. The FDA has a quick-step clearance for Stage II trials. The organisation discharged the cycles of eight members of varying dose thresholds of Stage I counteracting agent informations. The representatives of the set of $25 \mu \mathrm{g}$ are close to the cure sera. However, nAb levels were significantly higher than the healing sera levels in Members who obtained the $100 \mu \mathrm{g}$ dose. In the $25 \mathrm{mg}$ and $100 \mathrm{mg}$ dose cohorts, the vaccine was shown to be exceptionally effective and well lasting, although three participants had 3 systemic signs following the organisation of the existing measurements of $250 \mathrm{mg}$ dosage amounts (99).

\section{BNT162b1 (BioNTech FosunPharma Pfizer)}

BNT162b1 may be a codonoptimised mRNA vaccine that codes the specific target of $\mathrm{nAb}$ infection, trimerised SARS-CoV-2 RBD. The antibody demonstrates improved immunogenicity through the extension of the foldon trimerisation space derived from the T4 to the RBD antigen. The mRNA is typified in cationic lipid nanoparticles that are ionised $80 \mathrm{~nm}$ and which ensure its efficient transport. Step 1/2 clinical tests have discovered an improved RBD specific IgG antibody concentration of 8 to 46.3 times titer in geometric cruelty serum gain. The SARS-CoV-2 neutralising anticords were found to be 1,8 to 2,8 times as high as the SARS-CoV-2 crude geometric titers. There were no unfavourable effects for immediate and temporal neighbourhood reactions and processes. In both situations, the defence and resistance reactions were not measured over the past two weeks after the time calculations were coordinated. The findings from Israel demonstrate the effects of the vaccines administered outside clinical trials. They show early evidence that Pfizer-two-dose BioNTech's vaccine can prevent or limit infection in some vaccinated people. According to a preliminary analysis of 200,000 people older than 60 who received the vaccine, the chances of testing positive for the virus were $33 \%$ lower two weeks after the first injection. Preliminary clinical trials of the Pfizer-BioNTech vaccine show it to be around $90 \%$ effective at preventing COVID19 and some protection from infection. It will take a long time to show whether vaccinated people no longer carry the virus. More than $75 \%$ of older people in Israel have been vaccinated and should see a drop in hospitalisations over the coming weeks. Most countries are prioritising COVID-19 vaccinations for people who have a high risk of dying. The first evidence of success for shots will be a drop in the hospitalisation rates for people infected with the disease, and then a drop in the death rates (100).

\section{DNA Vaccines}

The most sophisticated immunisation strategy is the creation of a DNA antibody that codes an antigen and an adjuvant that drives the flexible, safe response. Transfected cells express the transgene, which provides the transgenic specific proteins with an unchanging supply that is quite close to the living infection. The antigenic material is also endocytosed by youthful dendritic cells which display, subsequently, convincing humours as well as cell-mediated safe reactions to the antigenes CD4 + and $\mathrm{CD} 8+\mathrm{T}$ cells onto the cell surface as an association with MHC 2 and MHC 1 antigens (101).

\section{Live Attenuated Vaccines}

It may be a SARS-CoV-2 prophylactic vaccine (102). The $\mathrm{S}$ protein classification of SARS-CoV-2 is used tailored for codon and is combined with $\operatorname{IgE}$ groundbreaking structure. The IgE-spike SARS-CoV-2 arrangement was synthesised using BamHI and XhoI and processed. Under the control of IE CMV and BGH polyadenylation flag, the treated DNA was joined with plastomide expression pGX0001. The close similarity of T functional antibodies and the cell reaction in the pre-clinical trials indicates that within 7 days of vaccination, the antibody will respond successfully. The antibody reached the clinical stage I trials (Stage I: NCT04336410). The members obtained 1,0 mg INO-4800 electric proportion by using CELLECTRA (B) 2000 gadget per visit for the sum of this stage of the clinical trials by July. The experiment will test an intradermal infusion antibody candidate's immunology and protection and tolerability and will evaluate the electroporation of strong human adults (102).

\section{DelNS1-SARS-CoV2-RBD (University of Hong Kong)}

This LAV is a strain of influenza vaccine with a cancellation of the NS1 mutation. It is reoriented and is formed within the life of the chicken, or Madin Darby Canine Crane Cells (MDCK) cells, to evaluate the RBD space for SARS-CoV-2 spike protein on their surface. It can be handled by a nasal shower rather than the wild kind of flu infect.

\section{Others}

Different immunisation candidates have been easily strengthened with probable but too antagonistic immunisation due to the composition and genome of the SRAS-CoV-2. In certain long-term clinical studies, the assignment of antimicrobial enhancement is long and lumbering. The British and American Tobacco Industry (BAT) late unfurl the immunisations of the COVID-19 utilising their unused and rapid-growing tobacco plant invention while Tianjin College has established a verbal antibody that used Saccharomyces cerevisiae to transport them effectively. Separate biotech wanders used numerous developments for the improvement of their vaccine candidates. The yeast status of GRAS (mainly respected as secure) provides high adaptability, vigour and costeffectiveness of endless steps needed in order to combat this widespread disease (103).

Further, it has been noticed that the WTAGAAYYY and YDPPLQPEL epitope clusters can be exploited for the description of epitope-based peptide vaccination in silico thinking using various databases such as VaxiJen (104).

\section{Self-Assembling Vaccine (HaloVax)}

In order to enforce the immune framework, the immunisation uses a warm stun protein (hsp). It consists of a protein mixture sandwiched between Avidin and HSP. To tailor immunisation (Voltron Therapeutics, Inc., 2020) Tables 2 is mixed with biotinylated immune peptides.

\section{Recombinant Vaccines/Viral Vectors}

Viral vector invention involves a transfer to an irrelevant, engineered infection of one or more qualities which cover a target antigen. The viral vector can be competent for replication (live weakened) or not. Antibodies that use viral vectors to count the adenovirus (WAR) for HIV, Ebola, Zika, and Chikungune were found to be able to stimulate cellular or humoral insusceptibility with a capacity to enhanced vesicular stomatitis (vSV), alphaviruses, poxviruses and herpes viruses that enabled the addition of $5 \mathrm{~kb}$ or more of transgenes (106). This stage concerns the possibly slower pace of anticörper-production in the 
Table 2. The vaccine development stages and the process (105)

\begin{tabular}{|c|c|c|}
\hline Phase & Aim & Features \\
\hline Exploratory & - Develop a vaccine & $\begin{array}{l}\text { - Research intensive phase } \\
\text { - Identify synthetic or natural antigen } \\
\text { - Develop a vaccine (natural or synthetic). Time: } 25 \text { years } \\
\text { - The success rate to proceed is } 40 \% \\
\text { - Causes of failure based on the nature of the pathogen }\end{array}$ \\
\hline Pre-clinical & $\begin{array}{l}\text { - The vaccine is safe and immunogenic } \\
\text { - Evaluate the starting dose for } \\
\text { human studies }\end{array}$ & $\begin{array}{l}\text { - Subjects: Vaccine is studied in Cell culture \& animals } \\
\text { - Design: Toxicity and antibody response, challenge studies. Time: }<1 \text { year } \\
\text { - The success to proceed is } 33 \%\end{array}$ \\
\hline $\begin{array}{l}\text { Clinical } \\
\text { Trial } \\
\text { Authorization }\end{array}$ & $\begin{array}{l}\text { - Allow human experiments } \\
\text { - (Application for IND) }\end{array}$ & $\begin{array}{l}\text { - The basis for Authorisation-Manufacturing steps \& analytical methods for } \\
\text { vaccine \& placebo production } \\
\text { - Availability and stability of vaccine \& placebo during clinical studies. } \\
\text { Time: within } 30 \text { days }\end{array}$ \\
\hline Phase I & $\begin{array}{l}\text { - First-in-human testing } \\
\text { - Vaccine safety and immune } \\
\text { response }\end{array}$ & $\begin{array}{l}\text { - Subjects: Healthy volunteers }(20-100) \\
\text { - Site: vicinity of the tertiary care for close observation } \\
\text { - Design: Escalation study to avoid severe adverse effects (SAEs) } \\
\text { - Monitor: Health outcomes (clinical and laboratory) and antibody } \\
\text { production. Time: a few mon } \\
\text { - The success rate to proceed } 66 \% \\
\text { - Caution: Follow strict go/no-go criteria based on safety and immunity data }\end{array}$ \\
\hline Phase II & $\begin{array}{l}\text { - Vaccine safety, immunity/ partial } \\
\text { efficacy } \\
\text { - Dose-response, schedule and } \\
\text { method of delivery }\end{array}$ & $\begin{array}{l}\text { - Subjects: Healthy volunteers (hundreds), may include a diverse set of humans } \\
\text { - Site: Community-based (university, colleges, schools, etc.) } \\
\text { - Study design: Studied against a placebo, adjuvant, or established vaccine } \\
\text { - Dose: Test vaccine in different schedules and a diverse set of humans } \\
\text { - Monitor: Health outcomes (clinical and laboratory) and antibody response } \\
\text { - Partial efficacy data can be procured under the circumstances. Time: } 2 \text { y } \\
\text { - The success rate to proceed } 30 \%\end{array}$ \\
\hline Phase III & - Vaccine efficacy and safety & $\begin{array}{l}\text { - Subjects: Target population (thousands) } \\
\text { - Site: Field conditions similar to future vaccine use } \\
\text { - Design: Vaccine randomized vis-a-vis a placebo, adjuvant, or an established vaccine } \\
\text { - Monitor: Vaccine efficacy and SAE } \\
\text { - Time: Many years } \\
\text { - The success rate to proceed } 70 \%\end{array}$ \\
\hline $\begin{array}{l}\text { Biologic } \\
\text { License } \\
\text { Application }\end{array}$ & - Marketing of vaccine & $\begin{array}{l}\text { - The basis for an approval-The vaccine is safe and effective in humans (Efficacy }>95 \% \text { ) } \\
\text { - Capacity to produce in bulk for market demand } \\
\text { - Affordable cost to a susceptible population }\end{array}$ \\
\hline Phase IV & - Postmarketing surveillance & $\begin{array}{l}\text { - Spontaneous reporting (Adverse Events Reporting System) } \\
\text { - Monitor: Data collected by the end-users }\end{array}$ \\
\hline
\end{tabular}

outbreak environment as testing facilities at Biosafety level 2 (BSL2) is necessary and imaginable pre-existing immunisation resistance to virus vectors, such as Ad5 and $\mathrm{MV}$, decreases the adequacy of the anticorps.

To illustrate this issue, approaches such as the collection of prevalent human Moo adenoviral serotypes (Ad26 or Ad35) were used. Ebola vaccine (rVSV-ZEBOV) is currently the authorised vector-based vaccine that has been licenced for human use and, as has occurred, has been developed and used to a small extent. The open name MERS-CoV (MVA-MERS-S DF1) immunisation was tested in a stage 1 study of 26 people matured from $18-55$, which involved the usage of a modified vaccine Ankara and the contact of the spike (S) protein MERSCoV. There seemed to be a positive safety profile without serious antagonisms, but the laughter and $\mathrm{T}$-cell response to the MERS CoV are mildly reduced (107).

It has been reassuringly taken into account that whilst a specific vector counteracting agent was evoked, counteracting agent reactions to the transgene after boosters inoculation have been evoked by the antibody. The ChAdOx1 MERS vaccine, a Phase 1 clinical trial with a replacement antibody, shows that a single measurement was capable of inspiring both attitude and cellular reactions toward MERS Co V, which was repeated with no simian adenoviral vector that communicates the spike protein $(\mathrm{S})$ in 24 individuals who had a ripening period of 18 to 50 .

\section{Nucleic Acid Vaccines}

Nucleic corrosive vaccines use antigen coding plasma plasmid DNA or RNA, RNA (mRNA) transmission individual or viral replica. The nucleic corrosive, if picked up by a cell, starts the protein blend in contrast to traditional diseases with the humoral and cell-mediated immune reactions. Veterinary irresistible pathogens, illustrated immunogenicity, foetus inflammation, mouth, deer powassan infections and rabies infection have been examined with this method of a vaccine. Step I tests are being performed in humans for Ebola, Flu, and Zika nucleic corrosive antibodies. The benefit of a nucleic corrosive stage is the simplicity of which antigen regulation and generation speed are achievable, as development can be produced in such a way that the criteria for BSL2 research facilities can be fully cell-free. There are disadvantages, such as fragile core corrosivity, especially mRNA, that the cold chain prepares for transport and capability on a continuous basis (108).

Clinical tests for SARS-CoV and MERS-CoV DNA antibody applicants in stage I have been performed. 10 adults have tested the SARS-CoV N-protein genome 
recombinant DNA vaccine candidate, developed by the National Sensitiveness and Irresistible Disease (NIAID) (109). The next number of representatives $(n=75)$ had been a MERS-CoV DNA immunisation (GLS-5300), developed by GeneOne Life Science / Inovio coding, and all had fulfilled safety profiles and inductible humoral and cellular reactions. The MERS-CoV DNA immunisation advanced into a clinical phase 2 study. The following number of participants were reported. An inactivated Immunisation (ISCV) given by Sinovac Biotech is the like-for-other SARS antibody that has entered a stage I study. No human spokesmen have been identified in which the signature virus threatened inoculated subjects.

\section{Peptide-Based Vaccines}

Using intramuscular or subcutaneous intramuscular injection, typically a viral peptide, or a mixture of recombinant energy tide, to induce a healthy reaction. The approach is generally stable, offers the option of the finest epitope as an antigen and promotes a strong, resistant reaction, particularly with adjuvants. Candidate antigenes are the full-range or S, M and N protein spacers of SARSCoV-2, since they have antibodies at least in the case of SARS-CoV at their producer stage. To improve the immunogenicity of viral peptides, the viral protein is also paired with an adjuvant or an epi-top which is recognised by the T- or B-cells. In addition, multi-epitope peptides may give a resistant reaction. The regularly rehabilitated organisation, a humoral and cellular-resistant reaction is essential. The transmission of a viral S protein component through a microneedle cluster is a late operation, which is restricted to routine subcutaneous infusion. Most of the composite proteins are produced and attempted to inoculate, comprising of a portion of viral $\mathrm{S}$ or $\mathrm{M}$ protein and an adjuvant, such as Aluminium. A dozen projects advance from preclinical consideration to early stage 1 and 2 clinical ponders in people through various phases of peptide-based vacuum cine.

\section{CURRENT SCENARIOS AND FUTURE IMPLICATION OF VACCINATION}

As COVID-19 vaccines are being deployed globally, researchers look forward for the early evidence its affects on the pandemic. Preliminary figures published recently in Israel showing that people who had been vaccinated were around a third less likely to test for SARS-CoV-2 positively than those who had not been getting vaccine shot. However, researchers suggest that it takes time to see the populational impact of immunisation. A variety of variables will allow us to detect the effects of vaccination on the pandemic as soon as possible. That includes the coverage of vaccination, the efficacy of shots on disease and infection prevention and the rate of viral transmission. The world's leading vaccination coverage is Israel and the United Arab Emirates. Around one-quarter of their populations have been vaccinated by both nations - more than $2 \mathrm{M}$ each. Other countries, including the UK and Norway, have targeted high-risk populations for their vaccine programmes. The UK has vaccinated more than 4 $\mathrm{M}$ people, mostly health professionals and elderly people, including caregivers. Norway has vaccinated about 40,000 residents in care homes (110).

India plans to vaccinate $300 \mathrm{M}$ people. The $30 \mathrm{M}$ healthcare employees, police and military, will be prioritised. The vaccine will be given to those over 50 and those suffering from co-morbid conditions. A free vaccine will be given. There are several doubts that the approval of Covaxin was premature. The findings from the Phase 3 trials have not been released. India's Drug Action Network is "baffled" by the FDA's decision to approve a vaccine that's still in trials. The government pledged that Covaxin, a government-run drug developed in collaboration with the Indian Council of Medical Research, will be available by August 2021. The vaccine will be manufactured by Oxford/AstraZeneca, which already has a stock of $40 \mathrm{M}$ doses available. The company vowed to produce $300 \mathrm{M}$ doses by July 2021 and said it would reserve $50 \%$ of its vaccine production for India (111).

After data have shown that it has provided limited protection from mild to moderate infections caused by the dominant coronavirus in the region, South Africa will stop using AstraZeneca's shot Covid 19 in their vaccination programme. Minister of Health, Zweli Mkhize said that after misleading results of a trial conducted by Université de la Witwatersrand, the government would await scientific advice on how to proceed. After receiving $1 \mathrm{M}$ doses provided by the Serum Institute of India on Monday, the government intended that the AstraZeneca be shot down soon by medical staff (112).

The creator of vaccines is now working by leaps and bounds for vaccines to improve their effectiveness against variants of spike protein mutations. Most of the vaccines have the protein bound to a human cell. The South African Spike series has been presented in the works. It's very likely that countries will be able to use a new version in the autumn. Several people will then have a third hunt later this year, which opens up the possibility. More than 100 South African cases have already been reported in the UK. In places where there has been a case, attempts are made to avoid the spread with quarantine measures for foreign tourists and home-to-house checks. "We are doing with influenza vaccines, whereby you look at the variant of viruses spreading around the world, you quickly produce a variant of vaccine and start vaccinating and protecting the nation," Zahawi told the BBC that in the coming years people should expect to see frequent Covid vaccines boosters.

In comparison to a reactive scheme which is introduced when a new pathogen emerges, a plan has now defined targets and initiatives which could start immediately at large. The approaches are understood, and infrastructure is developed thanks to work already done on other viruses, especially HIV and influenza. Investments in basic science - including virology, genomics, immunology and structural biology - have provided a great opportunity to further improve SARS-CoV-2 and make ready for new virus pathogens. The investment of $100 \mathrm{M}$ USD to $200 \mathrm{M}$ USD in trials per virus is anticipated to the range for many years.

It is visualised that public-private collaborations between governments, business and philanthropy will support these costs. Organisations such as CEPI, the COVAX and GAVI Facilities could assist in putting together resources and initiating negotiations to introduce the types of vaccine are proposing. There will be outbreaks in the future, and more epidemics will most likely happen. These pandemics must be prevented (113). The world pandemic also has besides 
the health and lives of the population, also a very substantial impact on the environment. The pandemic caused a substantial increase of single-use plastics (114), problems with plastic waste (115) and namely on toxic waste (116). It also has both ways impact on energy use as well as generation, and consequently, it is related to the increase of several environmental footprints, as Greenhouse Gases (GHG) Footprint, Nitrogen Footprint, Water Footprint and Plastic Waste Footprint (117). A vital issue is minimising the negative impacts on the society and industry with the post-pandemic perspective in mind (118).

\section{CONCLUSIONS AND LIMITATIONS}

In compliance with requirements established by the FDA and WHO, the immunisations applicant needs to pass the protection and viability of a minimum of three phases of placebo-controlled clinical trials, which may take time to complete. Given the severity of the large-scale economy, which limited a global shutdown, it is important to boost immunisation rapidly. A few designers suggest that regulated human challenge experts can perform the phase 3 training correctly to enable accelerated licencing of immunogenic immunisations. Any longer-term recommendations raised by immunisation should still be tested inside the extended sector pondering participants.

In addition, sometime recently, protection trial extended immunisation to these bunkers could be performed for rare bunches, infants and pregnant women and immunocompromised patients. Stable and viable antibodies are evaluated and encouraged on models of testing facilities for creatures. These animal models must behave as in human beings as a comparable path of illness. However, because of the difference between the ACE2 receptors of humans and mouse, the normal innate strains of mice are not helpless against COVID-20 contamination. The progression of the transgenic mouse demands that the hACE2 receptor be transmitted. Two creatures models were already developed for SARS-CoV (hACE2 transgenic mice and another, primate macaques prove), but the current situation needs that such creature models be continuously replicated and disseminated to satisfy analysts worldwide demands (119).

In the lungs of the Syrian hamsters, the SARS-CoV-2 distinction will efficiently be imitated. The lungs of infected hamsters are strongly linked to COVID 19 patients with pneumonia with obsessed injuries. Furthermore, the $\mathrm{nAb}$ response demonstrated by the infected hamster indicates insensitivity to the successive challenge. The conversion of the benefit force sera into the naive hamsters often monitored the reaction of the counteracting agent and thus hampered the viral replication in the lungs. The scope of such studies has demonstrated that Syrian hamster may be a result of recognising and assessing antiviral drugs and immunotherapies for SARS-CoV-2 pathogenesis (120).

By the way, the determination of the subordinate immunisation protected upgrade cannot be extrapolated from creature models and involves true analysis from arrangement III individual experimentation or recognition of the human challenge. The subordinate upgrade of counter spoken agents (ADE) is misused as an elective technique for contaminating a number of cells, with multiple infections such as Dengue, HIV, coronavirus etc. The anticorps-virus complex can attach to the FC receptors, trigger the additional structure or cause a conformational alteration within the viral enfolding glycoprotein. This method is tested for non-neutralising or insufficiently amounts of vaccine-induced antibodies. The preparation stimulates the viral entry into the cell since the virus antibody complexes are improved officially in efficiency to hold FcR cells. ADE discomfort has been shown by the clinical and preclinical studies performed by the SARS-CoV vaccine applicants. Improved Respiratory Infection Associated Immunisation (VAERD) also can be done by TH2 tolerant and complicated reactions (92). The viral genome is powerless to alter and may undergo antigenic motions and antigenic float, as it spreads between populations. This will vary in conjunction with the natural conditions and population thickness of a topographical range. The researchers could evaluate 198 transformations by screening the 7,500 samples of infected individuals, which would autonomously materialise and demonstrate the gradual progression of the human virus inside the patient. These adjustments can lead to diverse subtypes which will allow the infection, after the organisation of the antibody, to evade the safe structure actually.

Ethics Committee Approval: Since our study was a review, ethics committee approval was not required.

Conflict of Interest: None declared by the authors.

Financial Disclosure: None declared by the authors.

Acknowledgements: The authors are thankful to the Institute of Research and Consulting Studies at King Khalid University, Saudi Arabia for supporting this research through grant number 2-N20/22. The support of the Research Center for Advanced Materials Science is highly acknowledged. This research was also supported by a project "Sustainable Process Integration Laboratory SPIL", project No. CZ.02.1.01/0.0/0.0/15_003/0000456 funded by EU as "CZ Operational Programme Research, Development and Education”, Priority 1: Strengthening capacity for quality research.

\section{CRediT Authorship Contribution Statement}

Sami ULLAH: Conceptulisation, Consultation and Funding Acquisition; Abdullah G. AL-SEHEMI: Conceptulisation and Idea development, Jiří Jaromír KLEMEŠ: Writing, Editing and Proofreading, Funding Acquisition, Project administration, Supervision; Sanam SAQIB: Medical technical consultation; Sahibzada Muhammad Azib GONDAL: Medical technical consultation; Sidra SAQIB: Writing, Review and Editing, Data collection; Akasha ARSHAD: Writing, Review and Editing, Data collection; Hira SAQIB: Writing, Review and Editing, Data collection; Ahmad MUKHTAR: Writing - original draft, Visualisation, Data interpretation and Data analysis; Muhammad IBRAHIM: Writing and Editing; Saira ASIF: Visualisation, Writing and Editing, Data collection; Awais BOKHARI: Writing - original draft and proofreading, Data analysis, Visualisation, Supervision and Project administration. 


\section{REFERENCES}

1. Dyer O. Covid-19: Trump sought to buy vaccine developer exclusively for US, say German officials. BMJ. 2020;368:m1100.

2. Adegbola RA, Secka O, Lahai G, Lloyd-Evans N, Njie A, Usen S, et al. Elimination of Haemophilus influenzae type b (Hib) disease from The Gambia after the introduction of routine immunisation with a Hib conjugate vaccine: a prospective study. Lancet. 2005;366(9480):144-50.

3. Boopathi S, Poma AB, Kolandaivel P. Novel 2019 coronavirus structure, mechanism of action, antiviral drug promises and rule out against its treatment. J Biomol Struct Dyn. 2020; [Epub ahead of print]. doi:10.1080/07391102.2020.1758788

4. Walls AC, Park Y-J, Tortorici MA, Wall A, McGuire AT, Veesler D. Structure, function, and antigenicity of the SARS-CoV-2 spike glycoprotein. Cell. 2020;183(6):1735.

5. Tseng CT, Sbrana E, Iwata-Yoshikawa N, Newman PC, Garron T, Atmar RL, et al. Immunization with SARS coronavirus vaccines leads to pulmonary immunopathology on challenge with the SARS virus. PloS One. 2012;7(4):e35421.

6. Agrawal AS, Tao X, Algaissi A, Garron T, Narayanan K, Peng BH, et al. Immunization with inactivated Middle East Respiratory Syndrome coronavirus vaccine leads to lung immunopathology on challenge with live virus. Hum Vaccin Immunother. 2016;12(9):2351-6.

7. Delgado MF, Coviello S, Monsalvo AC, Melendi GA, Hernandez JZ, Batalle JP, et al. Lack of antibody affinity maturation due to poor Toll-like receptor stimulation leads to enhanced respiratory syncytial virus disease. Nat Med. 2009;15(1):34-41.

8. Sanche $\mathrm{S}$, Lin YT, $\mathrm{Xu} \mathrm{C}$, Romero-Severson E, Hengartner N, Ke R. High contagiousness and rapid spread of severe acute respiratory syndrome coronavirus 2. Emerg Infect Dis. 2020;26(7):1470-7.

9. Xiong TY, Redwood S, Prendergast B, Chen M. Coronaviruses and the cardiovascular system: acute and long-term implications. Eur Heart J. 2020;41(19):1798-1800.

10. Li B, Yang J, Zhao F, Zhi L, Wang X, Liu L, et al. Prevalence and impact of cardiovascular metabolic diseases on COVID-19 in China. Clin Res Cardiol. 2020;109(5):531-8

11. Grein J, Ohmagari N, Shin D, Diaz G, Asperges E, Castagna A, et al. Compassionate use of remdesivir for patients with severe Covid-19. N Engl J Med. 2020;382(24):2327-36.

12. Almedia J, Berry D, Cunningham C. Virology: Coronavirus. Nature. 1968;220(5168):650.

13. Forni D, Cagliani R, Clerici M, Sironi M. Molecular evolution of human coronavirus genomes. Trends Microbiol. 2017;25(1):35-48.

14. Ren LL, Wang YM, Wu ZQ, Xiang ZC, Guo L, Xu $\mathrm{T}$, et al. Identification of a novel coronavirus causing severe pneumonia in human: a descriptive study. Chin Med J (Engl). 2020;133(9):1015-24.

15. Chen H, Guo J, Wang C, Luo F, Yu X, Zhang W, et al. Clinical characteristics and intrauterine vertical transmission potential of COVID-19 infection in nine pregnant women: a retrospective review of medical records. Lancet. 2020;395(10226):809-15.

16. Li Q, Guan X, Wu P, Wang X, Zhou L, Tong Y, et al. Early transmission dynamics in Wuhan, China, of novel coronavirus-infected pneumonia. N Engl J Med. 2020;382(13):1199-1207.

17. Lei J, Li J, Li X, Qi X. CT imaging of the 2019 novel coronavirus (2019-nCoV) pneumonia. Radiology. 2020;295(1):18.

18. Huang C, Wang Y, Li X, Ren L, Zhao J, Hu Y, et al. Clinical features of patients infected with 2019 novel coronavirus in Wuhan, China. Lancet. 2020;395(10223):497-506.

19. Okba NMA, Müller MA, Li W, Wang C, GeurtsvanKessel $\mathrm{CH}$, Corman VM, et al. Severe acute respiratory syndrome coronavirus 2- specific antibody responses in coronavirus disease 2019 patients. Emerg Infect Dis. 2020;26(7):1478-88.

20. Gupta P. A Review: Epidemiology, pathogenesis and prospect in developing vaccines for novel coronavirus (COVID-19). Indian J Tuberc. 2020;[Epub ahead of print]. doi:10.1016/j.ijtb.2020.09.021

21. who.int [Internet]. World Health Organization. Coronavirus disease (COVID-19): Similarities and differences with influenza. [Cited: 2021 Jan 31]. Available from: https://www.who.int/news-room/qa-detail/coronavirus-disease-covid-19-similaritiesand-differences-with-influenza.

22. Chakraborty R, Parvez S. COVID-19: An overview of the current pharmacological interventions, vaccines, and clinical trials. Biochem Pharmacol. 2020;180:114184.

23. Wang Y, Zhang D, Du G, Du R, Zhao J, Jin Y, et al. Remdesivir in adults with severe COVID-19: a randomised, double-blind, placebo-controlled, multicentre trial. Lancet. 2020;395(10236):1569-78.

24. Chu CM, Cheng VC, Hung IF, Wong MM, Chan KH, Chan KS, et al. Role of lopinavir/ritonavir in the treatment of SARS: initial virological and clinical findings. Thorax. 2004;59(3):252-6.

25. Cao B, Wang Y, Wen D, Liu W, Wang J, Fan G, et al. A trial of lopinavir-ritonavir in adults hospitalized with severe Covid-19. N Engl J Med. 2020;382(19):1787-99.

26. Moreno L, Pearson AD. How can attrition rates be reduced in cancer drug discovery? Expert Opin Drug Discov. 2013;8(4):363-8.

27. Furuta Y, Komeno T, Nakamura T. Favipiravir (T705), a broad spectrum inhibitor of viral RNA polymerase. Proc Jpn Acad Ser B Phys Biol Sci. 2017;93(7):449-63.

28. Sonawane K, Barale SS, Dhanavade MJ, Waghmare SR, Nadaf NH, Kamble SA, et al. Homology modeling and docking studies of TMPRSS2 with experimentally known inhibitors Camostat mesylate, Nafamostat and Bromhexine hydrochloride to control SARS-Coronavirus-2. ChemRxiv. 2020. doi:10.26434/chemrxiv.12162360.v1

29. Zhu N, Zhang D, Wang W, Li X, Yang B, Song J, et al. A novel coronavirus from patients with pneumonia in China, 2019. N Engl J Med. 2020;382(8):727-33.

30. Gautret P, Lagier JC, Parola P, Hoang VT, Meddeb $\mathrm{L}$, Mailhe $\mathrm{M}$, et al. Hydroxychloroquine and azithromycin as a treatment of COVID-19: results of 
an open-label non-randomized clinical trial. Int $\mathbf{J}$ Antimicrob Agents. 2020;56(1):105949.

31. Zhou P, Yang XL, Wang XG, Hu B, Zhang L, Zhang $\mathrm{W}$, et al. A pneumonia outbreak associated with a new coronavirus of probable bat origin. Nature. 2020;579(7798):270-3.

32. Mehra MR, Desai SS, Ruschitzka F, Patel AN. Hydroxychloroquine or chloroquine with or without a macrolide for treatment of COVID-19: a multinational registry analysis. Lancet. 2020;[Epub ahead of print]. doi: 10.1016/S0140-6736(20)31180-6

33. Arshad S, Kilgore P, Chaudhry ZS, Jacobsen G, Wang DD, Huitsing $\mathrm{K}$, et al. Treatment with hydroxychloroquine, azithromycin, and combination in patients hospitalized with COVID-19. Int J Infect Dis. 2020;97:396-403.

34. Boulware DR, Pullen MF, Bangdiwala AS, Pastick KA, Lofgren SM, Okafor EC, et al. A randomized trial of hydroxychloroquine as postexposure prophylaxis for Covid-19. N Engl J Med. 2020;383(6):517-25.

35. Henao-Restrepo AM, Camacho A, Longini IM, Watson CH, Edmunds WJ, Egger M, et al. Efficacy and effectiveness of an rVSV-vectored vaccine in preventing Ebola virus disease: final results from the Guinea ring vaccination, open-label, clusterrandomised trial (Ebola Ça Suffit!). Lancet. 2017;389(10068):505-18.

36. Brende B, Farrar J, Gashumba D, Moedas C, Mundel T, Shiozaki Y, et al. CEPI-a new global R\&D organisation for epidemic preparedness and response. Lancet. 2017;389(10066):233-5.

37. Rauch S, Jasny E, Schmidt KE, Petsch B. New vaccine technologies to combat outbreak situations. Front Immunol. 2018;9:1963.

38. fda.gov [Internet]. Food and Drug Administration. Guidance for industry: General principles for the development of vaccines to protect against global infectious diseases. [Cited: 2021 Jan 31]. Available from: https://www.fda.gov/regulatory-information/searchfda-guidance-documents/general-principles-developmentvaccines-protect-against-global-infectious-diseases.

39. Plotkin S, Robinson JM, Cunningham G, Iqbal R, Larsen S. The complexity and cost of vaccine manufacturing- an overview. Vaccine. 2017;35(33):4064-71.

40. Callaway E. The race for coronavirus vaccines: a graphical guide. Nature. 2020;580(7805):576-7.

41. Lee CYP, Lin RTP, Renia L, Ng LFP. Serological approaches for COVID-19: Epidemiologic perspective on surveillance and control. Front Immunol. 2020;11:879.

42. Ewer KJ, Lambe T, Rollier CS, Spencer AJ, Hill AV, Dorrell L. Viral vectors as vaccine platforms: from immunogenicity to impact. Curr Opin Immunol. 2016;41:47-54.

43. Poland GA. Another coronavirus, another epidemic, another warning. Vaccine. 2020;38(10):v-vi.

44. Dömling A, Gao L. Chemistry and biology of SARSCoV-2. Chem. 2020;6(6):1283-95.

45. Yan R, Zhang Y, Li Y, Xia L, Guo Y, Zhou Q. Structural basis for the recognition of SARS-CoV-2 by full-length human ACE2. Science. 2020;367(6485):1444-8.

46. Wang Q, Zhang Y, Wu L, Niu S, Song C, Zhang Z, et al. Structural and functional basis of SARS-CoV-2 entry by using human ACE2. Cell. 2020;181(4):894-904.

47. Atri D, Siddiqi HK, Lang JP, Nauffal V, Morrow DA, Bohula EA. COVID-19 for the cardiologist: basic virology, epidemiology, cardiac manifestations, and potential therapeutic strategies. JACC: Basic Transl Sci. 2020;5(5):518-36.

48. Coulthard P. Dentistry and coronavirus (COVID-19)moral decision-making. Br Dent J. 2020;228(7):503-5.

49. Monteil V, Kwon H, Prado P, Hagelkrüys A, Wimmer RA, Stahl M, et al. Inhibition of SARSCoV-2 infections in engineered human tissues using clinical-grade soluble human ACE2. Cell. 2020;181(4):905-13.

50. Dhama K, Sharun K, Tiwari R, Dadar M, Malik YS, Singh KP, et al. COVID-19, an emerging coronavirus infection: advances and prospects in designing and developing vaccines, immunotherapeutics, and therapeutics. Hum Vaccin Immunother. 2020;16(6):1232-38.

51. Shih HI, Wu CJ, Tu YF, Chi CY. Fighting COVID19: a quick review of diagnoses, therapies, and vaccines. Biomed J. 2020;43(4):341-54.

52. Velavan TP, Meyer CG. The COVID-19 epidemic. Trop Med Int Health. 2020;25(3):278-80.

53. Zhang C, Wu Z, Li JW, Zhao H, Wang GQ. Cytokine release syndrome in severe COVID-19: interleukin-6 receptor antagonist tocilizumab may be the key to reduce mortality. Int $\mathbf{J}$ Antimicrob Agents. 2020;55(5):105954.

54. Chau VQ, Oliveros E, Mahmood K, Singhvi A, Lala A, Moss N, et al. The imperfect cytokine storm: severe COVID-19 with ARDS in patient on durable LVAD Support. JACC Case Rep. 2020;2(9):1315-20.

55. Tian X, Li C, Huang A, Xia S, Lu S, Shi Z, et al. Potent binding of 2019 novel coronavirus spike protein by a SARS coronavirus-specific human monoclonal antibody. Emerg Microbes Infect. 2020;9(1):382-5.

56. Cao YC, Deng QX, Dai SX. Remdesivir for severe acute respiratory syndrome coronavirus 2 causing COVID-19: An evaluation of the evidence. Travel Med Infect Dis. 2020;35:101647.

57. Lung J, Lin YS, Yang YH, Chou YL, Shu LH, Cheng $\mathrm{YC}$, et al. The potential chemical structure of antiSARS-CoV-2 RNA-dependent RNA polymerase. J Med Virol. 2020;92(6):693-7.

58. Gordon CJ, Tchesnokov EP, Feng JY, Porter DP, Götte $\mathrm{M}$. The antiviral compound remdesivir potently inhibits RNA-dependent RNA polymerase from Middle East respiratory syndrome coronavirus. J Biol Chem. 2020;295(15):4773-9.

59. Driggin E, Madhavan MV, Bikdeli B, Chuich T, Laracy J, Biondi-Zoccai G, et al. Cardiovascular considerations for patients, health care workers, and health systems during the COVID-19 pandemic. J Am Coll Cardiol. 2020;75(18):2352-71.

60. Kaplon H, Muralidharan M, Schneider Z, Reichert JM. Antibodies to watch in 2020. MAbs; 2020;12(1):1703531. 
61. Jean SS, Lee PI, Hsueh PR. Treatment options for COVID-19: The reality and challenges. J Microbiol Immunol Infect. 2020;53(3):436-43.

62. Cai Q, Yang M, Liu D, Chen J, Shu D, Xia J, et al. Experimental treatment with favipiravir for COVID19: an open-label control study. Engineering (Beijing). 2020;6(10):1192-98.

63. McKee DL, Sternberg A, Stange U, Laufer S, Naujokat C. Candidate drugs against SARS-CoV-2 and COVID-19. Pharmacol Res. 2020;157:104859.

64. Favalli EG, Ingegnoli F, De Lucia O, Cincinelli G, Cimaz R, Caporali R. COVID-19 infection and rheumatoid arthritis: Faraway, so close! Autoimmun Rev. 2020;19(5):102523.

65. Devaux CA, Rolain JM, Colson P, Raoult D. New insights on the antiviral effects of chloroquine against coronavirus: what to expect for COVID-19? Int J Antimicrob Agents. 2020;55(5):105938.

66. Colson P, Rolain JM, Lagier JC, Brouqui P, Raoult D. Chloroquine and hydroxychloroquine as available weapons to fight COVID-19. Int $\mathrm{J}$ Antimicrob Agents. 2020;55(4):105932.

67. Pandey A, Nikam AN, Shreya AB, Mutalik SP, Gopalan D, Kulkarni S, et al. Potential therapeutic targets for combating SARS-CoV-2: Drug repurposing, clinical trials and recent advancements. Life Sci. 2020;256:117883.

68. Zhu Y, Li J, Pang Z. Recent insights for the emerging COVID-19: drug discovery, therapeutic options and vaccine development. Asian J Pharm Sci. 2021;16(1):4-23.

69. Koirala A, Joo YJ, Khatami A, Chiu C, Britton PN. Vaccines for COVID-19: The current state of play. Paediatr Respir Rev. 2020;35:43-9.

70. Ojha R, Gupta N, Naik B, Singh S, Verma VK, Prusty $\mathrm{D}$, et al. High throughput and comprehensive approach to develop multiepitope vaccine against minacious COVID-19. Eur J Pharm Sci. 2020;151:105375.

71. Shang W, Yang Y, Rao Y, Rao X. The outbreak of SARS-CoV-2 pneumonia calls for viral vaccines. NPJ Vaccines. 2020;5:18.

72. Kim E, Erdos G, Huang S, Kenniston TW, Balmert $\mathrm{SC}$, Carey CD, et al. Microneedle array delivered recombinant coronavirus vaccines: Immunogenicity and rapid translational development. EBioMedicine. 2020;55:102743.

73. Dashraath P, Wong JLJ, Lim MXK, Lim LM, Li S, Biswas A, et al. Coronavirus disease 2019 (COVID19) pandemic and pregnancy. Am J Obstet Gynecol. 2020;222(6):521-31.

74. Ji H, Yan Y, Ding B, Guo W, Brunswick M, Niethammer A, et al. Novel decoy cellular vaccine strategy utilizing transgenic antigen-expressing cells as immune presenter and adjuvant in vaccine prototype against SARS-CoV-2 virus. Med Drug Discov. 2020;5:100026.

75. Modi P, Mihic M, Lewin A. The evolving role of oral insulin in the treatment of diabetes using a novel RapidMist $^{\mathrm{TM}}$ system. Diabetes Metab Res Rev. 2002;18(Suppl 1):S38-42.

76. Jia R, Yan L, Guo J. Enhancing the immunogenicity of a DNA vaccine against Streptococcus mutans by attenuating the inhibition of endogenous miR-9. Vaccine. 2020;38(6):1424-30.

77. Bolhassani A, Yazdi SR. DNA immunization as an efficient strategy for vaccination. Avicenna J Med Biotechnol. 2009;1(2):71-88.

78. Mahase E. Covid-19: Oxford vaccine is up to $90 \%$ effective, interim analysis indicates. BMJ. 2020;371:m4564.

79. Luo S, Zhang P, Ma X, Wang Q, Lu J, Liu B, et al. A rapid strategy for constructing novel simian adenovirus vectors with high viral titer and expressing highly antigenic proteins applicable for vaccine development. Virus Res. 2019;268:1-10.

80. Pardi N, Hogan MJ, Porter FW, Weissman D. mRNA vaccines - a new era in vaccinology. Nat Rev Drug Discov. 2018;17(4):261-79.

81. Feldman RA, Fuhr R, Smolenov I, Ribeiro AM, Panther L, Watson M, et al. mRNA vaccines against H10N8 and H7N9 influenza viruses of pandemic potential are immunogenic and well tolerated in healthy adults in phase 1 randomized clinical trials. Vaccine. 2019;37(25):3326-34.

82. John S, Yuzhakov O, Woods A, Deterling J, Hassett $\mathrm{K}$, Shaw CA, et al. Multi-antigenic human cytomegalovirus mRNA vaccines that elicit potent humoral and cell-mediated immunity. Vaccine. 2018;36(12):1689-99.

83. Richner JM, Himansu S, Dowd KA, Butler SL, Salazar V, Fox JM, et al. Modified mRNA vaccines protect against Zika virus infection. Cell. 2017;168(6):1114-25.e10.

84. Geall AJ, Verma A, Otten GR, Shaw CA, Hekele A, Banerjee $K$, et al. Nonviral delivery of selfamplifying RNA vaccines. Proc Natl Acad Sci USA. 2012;109(36):14604-9.

85. Baruah V, Bose S. Immunoinformatics-aided identification of $\mathrm{T}$ cell and $\mathrm{B}$ cell epitopes in the surface glycoprotein of 2019-nCoV. J Med Virol. 2020;92(5):495-500.

86. Ahmed SF, Quadeer AA, McKay MR. Preliminary identification of potential vaccine targets for the COVID19 coronavirus (SARS-CoV-2) based on SARS-CoV immunological studies. Viruses. 2020;12(3):254.

87. Bhattacharya M, Sharma AR, Patra P, Ghosh P, Sharma G, Patra BC, et al. Development of epitopebased peptide vaccine against novel coronavirus 2019 (SARS-COV-2): Immunoinformatics approach. J Med Virol. 2020;92(6):618-31.

88. who.int [Internet]. World Health Organization. Coronavirus disease 2019 (COVID-19): situation report, 82. [Cited: 2021 Jan 31]. Available from: https://apps.who.int/iris/handle/10665/331780.

89. Thanh Le T, Andreadakis Z, Kumar A, Gómez Román R, Tollefsen S, Saville M, et al. The COVID19 vaccine development landscape. Nat Rev Drug Discov. 2020;19(5):305-6.

90. Wang N, Shang J, Jiang S, Du L. Subunit vaccines against emerging pathogenic human coronaviruses. Front Microbiol. 2020;11:298.

91. Cao Y, Zhu X, Hossen MN, Kakar P, Zhao Y, Chen $X$. Augmentation of vaccine-induced humoral and cellular immunity by a physical radiofrequency adjuvant. Nat Commun. 2018;9(1):3695. 
92. Graham BS. Rapid COVID-19 vaccine development. Science. 2020;368(6494):945-6.

93. Tu YF, Chien CS, Yarmishyn AA, Lin YY, Luo YH, Lin YT, et al. A review of SARS-CoV-2 and the ongoing clinical trials. Int J Mol Sci. 2020;21(7):2657.

94. Lee J. marketwatch.com [Internet]. MarketWatch. These 23 companies are working on coronavirus treatments or vaccines - here's where things stand. [Cited: 2020 Aug 8]. Available from: https://www.marketwatch.com/story/these-ninecompanies-are-working-on-coronavirus-treatmentsor-vaccines-heres-where-things-stand-2020-03-06.

95. Funk CD, Laferrière C, Ardakani A. A snapshot of the global race for vaccines targeting SARS-CoV-2 and the COVID-19 pandemic. Front Pharmacol. 2020;11:937.0937

96. Hamilton E. wisc.edu [Internet]. University of Wisconsin-Madison. UW-Madison, FluGen, Bharat Biotech to develop CoroFlu, a coronavirus vaccine. [Cited: 2020 Sep 27]. Available from: https://news.wisc. edu/uw-madison-flugen-bharat-biotech-to-developcoroflu-a-coronavirus-vaccine/\#: :text=An $\% 20$ international $\% 20$ collaboration $\% 20$ of $\% 20$ virologists, vaccine $\% 20$ candidate $\% 20 \mathrm{known} \% 20 \mathrm{as} \% 20 \mathrm{M} 2 \mathrm{SR}$.

97. van Doremalen N, Lambe T, Spencer A, BelijRammerstorfer S, Purushotham JN, Port JR, et al. ChAdOx1 nCoV-19 vaccination prevents SARSCoV-2 pneumonia in rhesus macaques. Nature. 2020;586(7830):578-82.

98. Mulligan MJ, Lyke KE, Kitchin N, Absalon J, Gurtman A, Lockhart S, et al. Phase I/II study of COVID-19 RNA vaccine BNT162b1 in adults. Nature. 2020;586(7830):589-93.

99. modernatx.com [Internet]. Moderna. Moderna announces positive interim phase 1 data for its mRNA vaccine (mRNA-1273) against novel coronavirus. [Cited: 2021 Jan 31]. Available from: https://investors.modernatx.com/newsreleases/news-release-details/moderna-announcespositive-interim-phase-1-data-its-mrna-vaccine.

100. Mallapati S. Are COVID vaccination programmes working? Scientists seek first clues. Nature. 2021;589(7843):504-5.

101. Hobernik D, Bros M. DNA vaccines-how far from clinical use? Int J Mol Sci. 2018;19(11):3605.

102. clinicaltrials.gov [Internet]. ClinicalTrials.gov. Safety, tolerability and immunogenicity of INO-4800 for COVID-19 in healthy volunteers. [Cited: 2020 Nov 29]. Available from: https://clinicaltrials.gov/ct2/show/NCT04336410.

103. Zhai P, Ding Y, Wu X, Long J, Zhong Y, Li Y. The epidemiology, diagnosis and treatment of COVID19. Int J Antimicrob Agents. 2020;55(5):105955.

104. Garg P, Srivastava N, Srivastava P. An integrated insilico approach to develop epitope-based peptide vaccine against SARS-CoV-2. Preprints. 2020. doi:10.20944/preprints202005.0401.v1

105. Khuroo MS, Khuroo M, Khuroo MS, Sofi AA, Khuroo NS. COVID-19 vaccines: A race against time in the middle of death and devastation! J Clin Exp Hepatol. 2020;10(6):610-21.
106. Edridge AWD, Kaczorowska J, Hoste ACR, Bakker M, Klein M, Loens K, et al. Seasonal coronavirus protective immunity is short-lasting. Nat Med. 2020;26(11):1691-3.

107. Koch T, Dahlke C, Fathi A, Kupke A, Krähling V, Okba NMA, et al. Safety and immunogenicity of a modified vaccinia virus Ankara vector vaccine candidate for Middle East respiratory syndrome: an open-label, phase 1 trial. Lancet Infect Dis. 2020;20(7):827-38.

108. Zhang C, Maruggi G, Shan H, Li J. Advances in mRNA vaccines for infectious diseases. Front Immunol. 2019;10:594.

109. Martin JE, Louder MK, Holman LA, Gordon IJ, Enama ME, Larkin BD, et al. A SARS DNA vaccine induces neutralizing antibody and cellular immune responses in healthy adults in a Phase I clinical trial. Vaccine. 2008;26(50):6338-43.

110. Petersen HE. theguardian.com [Internet]. The Guardian. India's approval of Covid vaccines triggers mass immunisation drive. [Cited: 2021 Feb 8]. Available from: https:/www.theguardian.com/world/ 2021/jan/03/indias-approval-of-twin-vaccinestriggers-mass-immunisation-drive.

111. Eyal N, Lipsitch M, Smith PG. Human challenge studies to accelerate coronavirus vaccine licensure. $\mathrm{J}$ Infect Dis. 2020;221(11):1752-6.

112. cnbc.com [Internet]. CNBC. South Africa halts AstraZeneca vaccinations after data shows little protection against mutation. [Cited: 2021 Feb 9]. Available from: https://www.cnbc.com/2021/02/07/ south-africa-halts-astrazeneca-vaccinations-.html.

113. Burton DR, Topol EJ. Variant-proof vaccines - invest now for the next pandemic. Nature. 2021;590(7846):386-8.

114. Klemeš JJ, Fan YV, Tan RR, Jiang P. Minimising the present and future plastic waste, energy and environmental footprints related to COVID-19. Renew Sustain Energy Rev. 2020;127:109883.

115. Klemeš JJ, Fan YV, Jiang P. Plastics: friends or foes? The circularity and plastic waste footprint. Energ Source Part A. 2020; [Epub ahead of print]. doi:10.1080/15567036.2020.1801906

116. Fan YV, Jiang P, Hemzal M, Klemeš JJ. An update of COVID-19 influence on waste management. Sci Total Environ. 2021;754:142014.

117. Klemeš JJ, Fan YV, Jiang P. The energy and environmental footprints of COVID-19 fighting measures-PPE, disinfection, supply chains. Energy (Oxf). 2020;211:118701.

118. Klemeš JJ, Fan YV, Jiang P. COVID-19 pandemic facilitating energy transition opportunities. Int $\mathrm{J}$ Energy Res. 2020; [Epub ahead of print]. doi:10.1002/er.6007

119. Bao L, Deng W, Huang B, Gao H, Liu J, Ren L, et al. The pathogenicity of SARS-CoV-2 in hACE2 transgenic mice. Nature. 2020;583(7818):830-3.

120. Imai M, Iwatsuki-Horimoto K, Hatta M, Loeber S, Halfmann PJ, Nakajima N, et al. Syrian hamsters as a small animal model for SARS-CoV-2 infection and countermeasure development. Proc Natl Acad Sci USA. 2020;117(28):16587-95. 